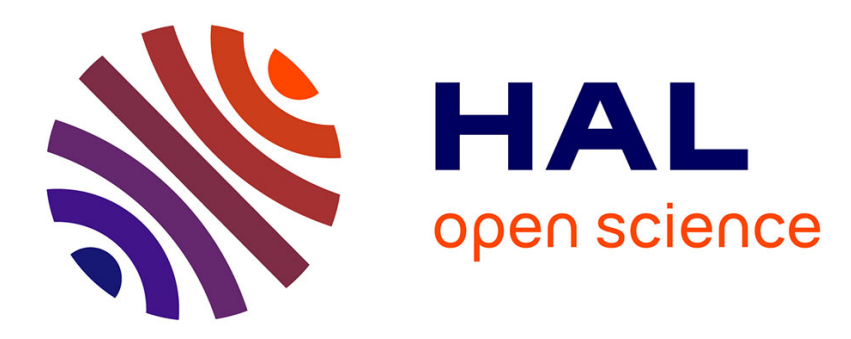

\title{
Weed resistance to acetyl coenzyme A carboxylase inhibitors: an update
}

Christophe C. Delye

\section{To cite this version:}

Christophe C. Delye. Weed resistance to acetyl coenzyme A carboxylase inhibitors: an update. Weed Science, 2005, 53 (5), pp.728-746. hal-02683479

\section{HAL Id: hal-02683479 \\ https://hal.inrae.fr/hal-02683479}

Submitted on 1 Jun 2020

HAL is a multi-disciplinary open access archive for the deposit and dissemination of scientific research documents, whether they are published or not. The documents may come from teaching and research institutions in France or abroad, or from public or private research centers.
L'archive ouverte pluridisciplinaire $\mathbf{H A L}$, est destinée au dépôt et à la diffusion de documents scientifiques de niveau recherche, publiés ou non, émanant des établissements d'enseignement et de recherche français ou étrangers, des laboratoires publics ou privés. 


\section{Weed resistance to acetyl coenzyme A carboxylase inhibitors: an update}

Christophe Délye

UMR Biologie et Gestion des Adventices, Institut National de la Recherche Agronomique, BP 86510, F-21065 Dijon cédex, France; delye@dijon.inra.fr

\begin{abstract}
Herbicides targeting grass plastidic acetyl coenzyme A carboxylase (ACC) are effective selective graminicides. Their intensive use worldwide has selected for resistance genes in a number of grass weed species. Biochemistry and molecular biology have been the means of determining the herbicidal activity and selectivity toward crop plants of ACC-inhibiting herbicides. In recent years, elucidation of the tridimensional structure of ACC and identification of five amino acid residues within the ACC carboxyl transferase domain that are critical determinants for herbicide sensitivity shed light on the basis of ACC-based resistance to herbicides. However, metabolism-based resistance to ACC-inhibiting herbicides is much less well known, although this type of resistance seems to be widespread. A number of genes thus endow resistance to ACC-inhibiting herbicides, with the possibility for various resistance genes that confer dominant resistance at the herbicide field rate to accumulate within a single weed population or plant. This, together with a poor knowledge of the genetic parameters driving resistance, renders the evolution of resistance to ACC-inhibiting herbicides unpredictable. Future research should consider developing tactics to slow the spread of resistance. For this purpose, it is crucial that our understanding of metabolismbased resistance improves rapidly because this mechanism is complex and can confer resistance to herbicides with different target sites.
\end{abstract}

Key words: ACCase, acetyl-CoA carboxylase, aryloxyphenoxypropionate, cyclohexanedione, target site, molecular modeling, mutation, metabolism, cross-resistance, fitness, genetic polymorphism, interspecific crosses, selection.
Weeds are a continuing problem in agriculture. The introduction of selective herbicides since the late 1940s has greatly facilitated farmers' work by suppressing the need for manual weeding. However, reliance on herbicides for weed control has resulted in shifts in the weed flora and, more importantly, in the selection of herbicide-resistant weed populations. This is particularly true for herbicides with a single target, such as herbicides inhibiting acetyl coenzyme A carboxylase (ACC). ACC inhibitors are a group of commercially important, very effective, selective graminicides that are applied postemergence. They are also known as group A herbicides (Anonymous 2004) or group 1 herbicides (Mallory-Smith and Retzinger 2003). Since their introduction in the late 1970s, the ACC-inhibiting herbicides have been widely used worldwide to control a number of grass weed species (Devine and Shimabukuro 1994). As a consequence, they rapidly selected, and are still selecting, resistant plants within grass weed species. Since 1994, when resistance to ACC-inhibiting herbicides was last reviewed in detail (Devine and Shimabukuro 1994), the number of grass weed species in which resistant plants have been reported has increased from 9 to $>34$ (Heap 2004). Resistance to ACC-inhibiting herbicides has now been reported in 26 countries. The estimates of cultivated land surfaces concerned by this resistance vary between 3 to $>4.6$ million ha (Heap 2004). Along with the development of resistance to ACC-inhibiting herbicides, our understanding of the mechanisms endowing this resistance has progressed substantially, largely owing to the use of molecular biology techniques. The purpose of this review therefore is to summarize what we have learned about ACC and the evolution of grass weed populations toward resistance to ACC-inhibiting her- bicides during the last decade. Available data about ACCs and ACC inhibitors and their mode of action will be reviewed; the focus is set first on the mechanisms endowing resistance and second on the evolution of resistance in grass weeds.

\section{Plant ACCs}

\section{ACC Isoforms}

ACC (EC 6.4.1.2) is a biotinylated enzyme that catalyzes the ATP-dependent carboxylation of acetyl coenzyme A into malonyl coenzyme A in a two-step, reversible reaction: $\mathrm{HCO}_{3}^{-}+$ACC-biotin + ATP $\leftrightarrow$ ACC-biotin- $-\mathrm{CO}_{2}^{-}+$ADP $+\mathrm{Pi}$, and ACC-biotin- $\mathrm{CO}_{2}^{-}+$acetyl coenzyme $\mathrm{A} \leftrightarrow \mathrm{ACC}-$ biotin + malonyl coenzyme A.

This reaction is the first step in the synthesis of fatty acids. In plants, large amounts of malonyl coenzyme A are needed in the plastids to sustain de novo fatty acid biosynthesis. Malonyl coenzyme A is also needed in the cytosol for a variety of reactions, including the elongation of very long chain fatty acids, the synthesis of secondary metabolites (e.g., flavonoids, anthocyanins), and the malonylation of secondary metabolites (Harwood 1988). The plastid envelope not being permeable to malonyl coenzyme A, this led to the hypothesis that at least two ACC isoforms are present in the cytosol and in the plastids of plants, respectively. It was not before the mid-1990s that the structure of ACC isoforms was clearly understood (Konishi and Sasaki 1994; Konishi et al. 1996; Sasaki et al. 1995; also see Incledon and Hall [1997] for a history of ACC structure elucidation). All ACC isoforms contain three catalytic domains, namely the biotin carboxyl-carrier (BCC), the biotin carboxylase 


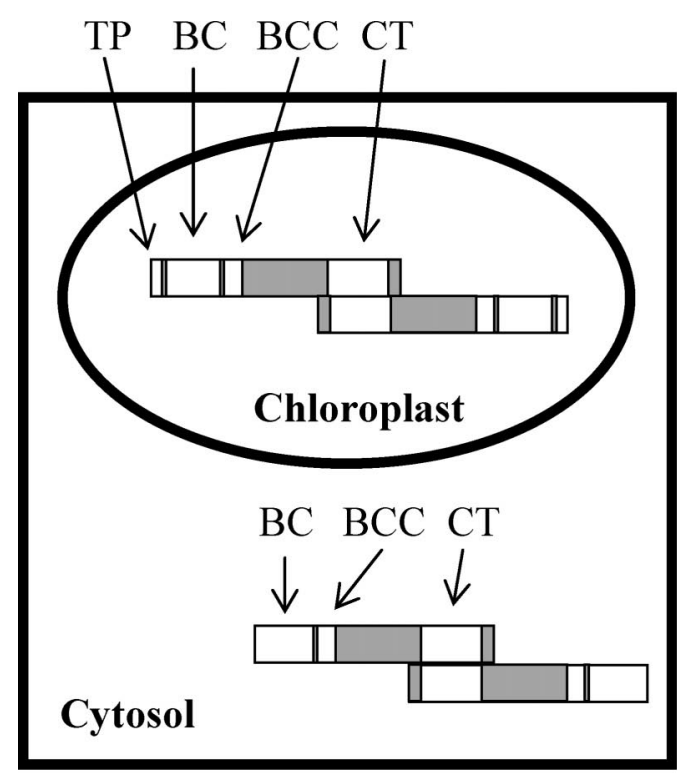

Poaceae (grasses)

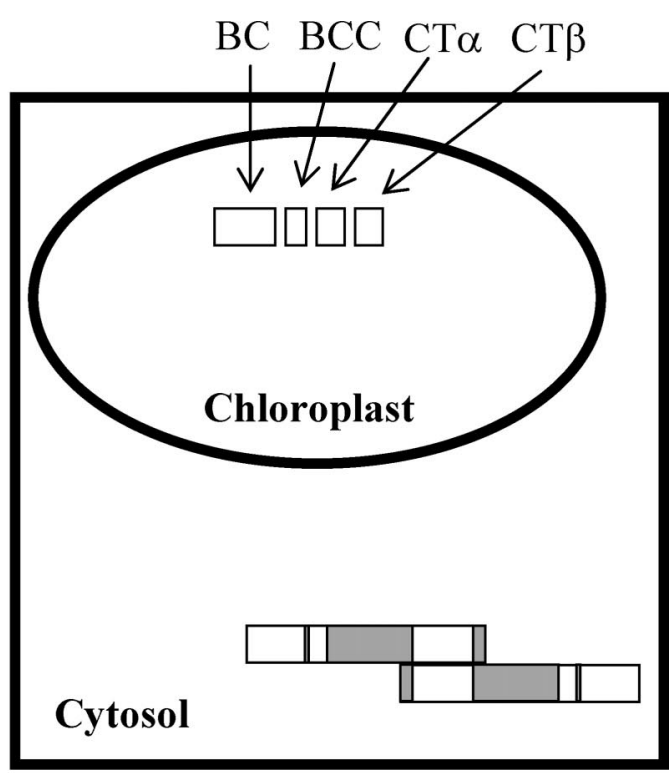

Most other plants

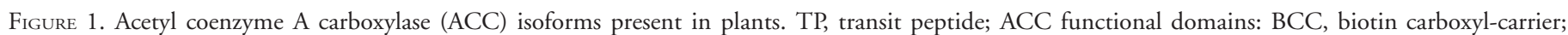

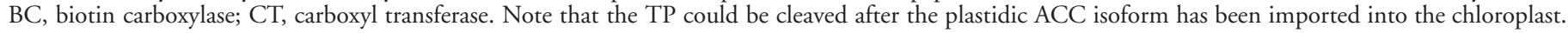

(BC), and the carboxyl transferase (CT) domains (Nikolau et al. 2003). The BC domain catalyzes the ATP-dependent carboxylation of a biotin group covalently linked to a lysine (Lys) residue in the BCC domain. The CT domain thereafter catalyzes the transfer of the carboxyl group from biotin to acetyl coenzyme A.

The plastidic ACC isoform accounts for $>80 \%$ of the total ACCase activity in leaves (Ashton et al. 1994; De Prado et al. 2000; Egli et al. 1993). In most plant species, it is a heteromeric enzyme composed of four distinct subunits: two for the CT domain and one for each of the BC and BCC domains (Figure 1). Readers are referred to recent reviews (Nikolau et al. 2003; Sasaki and Nagano 2004) for detailed descriptions of heteromeric ACC. In contrast, the ACC isoforms occurring in the cytosol in all plants and in the plastids and mitochondria in Poaceae (grasses) are large, homomeric enzymes carrying all three functional domains on a single polypeptide (Focke et al. 2003; Nikolau et al. 2003; Figures 1 and 2). All homomeric ACCs share a high degree of sequence conservation. The major difference between homomeric ACC isoforms is the presence of about 100 extra amino acids at the $N$-terminal end of the plastidic and mitochondrial isoform (Figure 2) that likely form a dual-targeting transit peptide sequence (Peeters and Small 2001). The transit peptide enables this ACC isoform to be directed to chloroplasts and mitochondria.

The distinction between grasses and other plants might not be clear-cut however. The plastids of some species in the dicotyledonous family Geraniaceae do not contain a heteromeric ACC and probably contain a homomeric isoform of this enzyme instead (Christopher and Holtum 2000). Furthermore, the plastids of dicotyledonous species such as Brassica napus L. and Arabidopsis thaliana L. contain both a heteromeric and a homomeric ACC isoform (Nikolau et al. 2003).

\section{Tridimensional Structure of Homomeric ACC}

Two homomeric ACC polypeptides have long been proposed to associate in a $500-\mathrm{kDa}$ homodimer to yield the active ACC enzyme (Egli et al. 1993), although there has been some controversy regarding the possible role of low molecular mass proteins as being part of the active ACC (Incledon and Hall 1997). The dimeric structure of active homomeric ACC has recently been established by crystallization of a functional CT domain from yeast ACC in com-

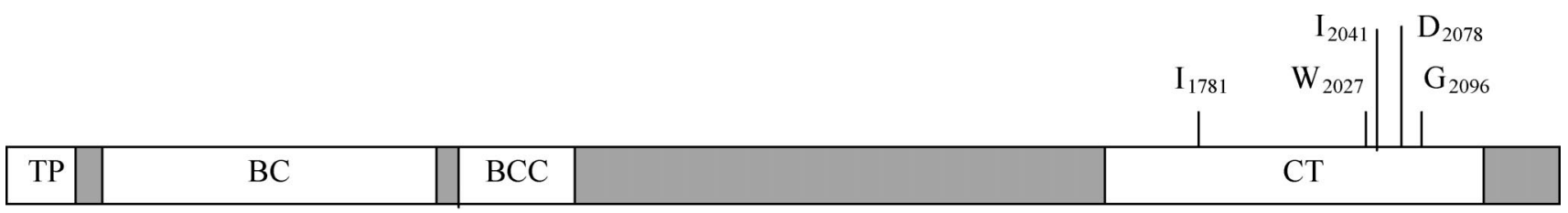

100 amino acids

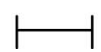

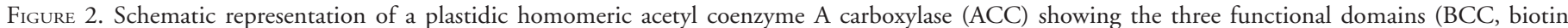

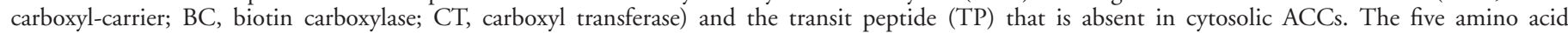

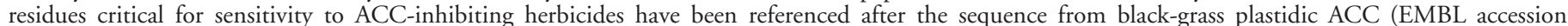
AJ310767). 
TABLE 1. Complete higher plant acetyl coenzyme A carboxylase sequences.

\begin{tabular}{|c|c|c|c|c|}
\hline Species & Isoform & $\begin{array}{c}\text { Length } \\
\text { (amino acids) }\end{array}$ & $\begin{array}{c}\text { EMBL/Genbank/DDBJ } \\
\text { accession number }\end{array}$ & Source \\
\hline Blackgrass & Plastidic & 2320 & AJ310767 & cDNA \\
\hline Arabidopsis thaliana L. & Plastidic $^{\mathrm{a}}$ & 2375 & AF062308 & gDNA \\
\hline A. thaliana & Cytosolic & 2254 & AF062308 & gDNA \\
\hline Canola & Plastidic $^{\mathrm{a}}$ & 2304,2321 & X77576, AJ131865 & gDNA \\
\hline Soybean & Cytosolic & 2261 & L42814 & gDNA \\
\hline Alfalfa & Cytosolic & 2257 & L25042 & cDNA \\
\hline Rice & Cytosolic & 2267 & AC092548 & gDNA \\
\hline Foxtail millet & Plastidic & 2321 & AF294805 & cDNA \\
\hline Wheat & Plastidic & 2253 & AF029895 & cDNA \\
\hline Wheat & Cytosolic & 2260 & U39321 & gDNA \\
\hline Corn & Plastidic & 2325 & U19183 & cDNA \\
\hline
\end{tabular}

a On the basis of the presence of a putative transit peptide.

plex with its substrate, acetyl coenzyme A (Zhang et al. 2003). The ACC CT dimer consists of the head-to-tail arrangement of two CT monomers, creating two active site cavities per dimer. Acetyl coenzyme A enters these cavities to undergo carboxylation into malonyl coenzyme A (Zhang et al. 2003).

\section{Natural Variation at Homomeric ACCs}

Homomeric ACCs are large proteins consisting of around 2,300 amino acids (Figure 2), meaning that the corresponding cDNAs are about 7,000 bp in length. To further complicate the situation, the genes encoding plant homomeric ACCs have a complex intron-exon structure. The coding sequence of the gene encoding wheat (Triticum aestivum $\mathrm{L}$.) cytosolic ACC is interrupted by no less than 28 introns (Podkowinski et al. 1996), whereas those of the gene encoding the plastidic ACC in blackgrass (Alopecurus myosuroides Huds.) and green foxtail [Setaria viridis (L.) Beauv.] are interrupted by 32 introns (Délye, unpublished data). This means entire ACC genes are around 15,000 bp in length. These are good reasons why so few plant ACC genes are fully known to date (Table 1). In diploid grasses, a single nuclear gene (Gornicki et al. 1997; Huang et al. 2002) generally encodes the plastidic and mitochondrial homomeric ACC isoform, although two genes might exist in Lolium spp. (Huang et al. 2002). The situation seems more complex for the cytosolic ACC isoform, which might be encoded by several genes distinct from that encoding the plastidic and mitochondrial isoform. At least five distinct genes encoding cytosolic ACC isoforms have been identified in hexaploid wheat (Faris et al. 2001). As a consequence of all that precedes, few data are available on variability of ACC genes.

From the ACC sequences available, it appears that hom-<smiles>[R1]O/N=C(\[R3])C1=C(O)C([R2])C([R])CC1=O</smiles><smiles>[R]Oc1ccc(OC(C)C(=O)O)cc1</smiles>

FIGURE 3. Generic structures of the aryloxyphenoxypropionate (APP, right) and cyclohexanedione (CHD, left) herbicides. Developed formulas of commercial compounds are available in Heap (2004). omeric ACC proteins are highly conserved among and within species. Amino acid sequences of grass plastidic ACCs share $>80 \%$ identity. They display $>65 \%$ identity with the amino acid sequences of plant cytosolic ACCs, and as much as $52 \%$ identity with the amino acid sequence of a cytosolic isoform from an organism as phylogenetically distant as yeast. This data, together with a recent study that revealed an excess of synonymous vs. nonsynonymous nucleotide variation within the CT domain of blackgrass plastidic ACC (Délye et al. 2004b), strongly suggest that ACC is a gene under purifying selection (i.e., that nonsynonymous mutations cannot occur anywhere within the gene without deleterious consequences).

\section{Herbicides Inhibiting ACCs}

\section{Structure and Mode of Action of ACC-Inhibiting Herbicides}

ACC inhibitors are a group of commercially important herbicides enabling efficient management of grass weed species. They belong to two chemical families: aryloxyphenoxypropionates (APPs), also known as "fops," and cyclohexanediones (CHDs), also known as "dims" (Secor et al. 1989). Although APP and CHD molecules all consist of a hydrophobic carbon skeleton with polar substituents, the molecules in the two families display rather dissimilar structures (Figure 3). APPs and CHDs show nearly competitive inhibition with respect to the substrate acetyl coenzyme A, which suggests a binding site at ACC CT site (Burton et al. 1991; Rendina et al. 1990). Because APPs and CHDs are mutually exclusive inhibitors, it was proposed that their binding sites on ACC CT overlap but are not the same (Burton et al. 1991; Rendina et al. 1990). ACC inhibition will block fatty acid biosynthesis; consequently, cell membrane integrity will be altered, thus causing metabolite leakage and rapid plant death (Devine and Shimabukuro 1994). The generation of cytotoxic hydroperoxides as a secondary consequence of the disruption of fatty acid biosynthesis has also been proposed to be a primary cause for the toxicity of ACC-inhibiting herbicides (Cummins et al. 1999).

The activity of APPs and CHDs against ACC is limited by strict structural requirements (Turner and Pernich 2002; Webb et al. 2000). For instance, only $R(+)$ enantiomers of APPs are active against ACC, whereas $S(-)$ enantiomers are not (Gerwick et al. 1988; Rendina et al. 1988; Walker et 
al. 1988). Large substituents at positions R1 and R4 (Figure 3 ) in CHDs confer high inhibitory activity against ACC, whereas large substituents at position R2 are associated with poor inhibitory activity (Webb et al., 2000).

Recent studies have confirmed the mode of action of APPs and CHDs. First, heterologous expression of chimeric ACCs in yeast have shown that some determinants of sensitivity to APPs and CHDs were located on a 400-amino acid fragment of wheat plastidic ACC encompassing a section of the CT domain (Nikolskaya et al. 1999). Further works that will be discussed more in detail in the "Molecular basis of resistance to ACC inhibitors" section showed that two regions of the CT domain of plastidic ACC are critical for sensitivity to APPs and CHDs (Délye et al. 2002c, 2003, 2005; Zagnitko et al. 2001). The definite evidence that APPs and CHDs bind to the homomeric ACC CT domain came from the determination of the three-dimensional structure of yeast cytosolic ACC CT domain dimers cocrystallized with bound APP molecules (Zhang et al. 2004b). APPs were shown to bind inside the active site cavity of ACC CT dimers. Binding of one APP molecule inside one of the two active sites of a CT dimer caused conformational changes in the structure of the whole dimer (Zhang et al. 2004b). These changes were incompatible with the binding of acetyl coenzyme A and malonyl coenzyme A molecules for catalysis, in agreement with biochemical data showing that APPs are nearly competitive inhibitors of acetyl coenzyme A (Burton et al. 1991; Rendina et al. 1990; Zhang et al. 2004b). Conformational changes exposed the core of the CT domain dimer bound with an APP molecule, which could facilitate the binding of a second APP molecule inside the second active site of the CT dimer (Zhang et al. $2004 \mathrm{~b}$ ). This agrees with a previous demonstration of positive cooperativity for APP binding to homomeric cytosolic ACCs obtained by analysis of the kinetics of herbicide binding (Herbert et al. 1996b).

The use of tridimensional protein modeling that is based on the structure of the yeast cytosolic ACC CT domain and the similar ACC-inhibiting features of CHDs and APPs allowed the proposition that, in plant plastidic homomeric ACCs, CHDs bind inside the CT dimer active site cavity like APPs to exert their ACC-inhibiting effect (Délye et al. 2005). However, a major limit to the use of models is that crystallographic data for the tridimensional structure of the ACC CT domain have been obtained from the yeast homomeric cytosolic ACC, which is considerably less sensitive to APPs and CHDs than the grass plastidic isoform (Joachimiak et al. 1997; Nikolskaya et al. 1999; Table 2). Furthermore, homomeric plastidic ACC isoforms from grasses do not exhibit cooperativity for APP binding (Herbert et al. 1996b). Thus, if the general binding mode of ACC inhibitors inside the CT active site cavity is very likely similar for both plastidic and cytosolic isoforms given the conservation among homomeric ACC proteins, it clearly displays differences in the detail of the interactions involved (Délye et al. 2005).

Molecular and biochemical data have clearly established that the CT domain of the homomeric ACC is the primary target site for APPs and CHDs. Alternative modes of action proposed, such as the possibility that these herbicides are auxin antagonists that bind to putative cell membrane receptors to induce rapid depolarization of the membrane and cell death via oxidative damage (Ratterman and Balke 1988; Shimabukuro et al. 2001), can thus be discounted. Although APPs and CHDs do depolarize cell membranes in vitro (e.g., Holtum et al. 1994; Ratterman and Balke 1988; Vila-Aiub et al. 2003), this might not occur in vivo at herbicide field rates. Depolarization of the cell membrane is very likely a secondary effect after ACC inhibition and the ensuing disruption of the fatty acid biosynthesis pathway, as has been proposed before (Di Tomaso 1994; Incledon and Hall 1997).

\section{Selectivity of ACC-Inhibiting Herbicides Toward Crop Plants}

\section{Selectivity on the Basis of Differences in ACC Sensitivity}

At field rates, APPs and CHDs strictly target grass species, apart from a few exceptions discussed before. This can be related to the high sensitivity of chloroplastic homomeric ACC to these herbicides (Table 2). Field rates of APPs and CHDs do not affect most other plant species or animals. The basis for selectivity toward the vast majority of nongrass plant species resides in the insensitivity of the heteromeric ACC that is present in the plastids of these species to APP and CHD action (Alban et al. 1994; Burton et al. 1987). The structure of heteromeric ACCs is highly different from that of homomeric ACCs (Figure 1), which is very likely the basis for heteromeric ACC insensitivity. Other organisms, such as animals or fungi, only contain homomeric ACC isoforms. Considerable differences have been observed in the activity of distinct APP or CHD molecules against a given homomeric ACC isoform, as well as among homomeric ACC isoforms for a given ACC inhibitor (Table 2). Although some of the differences observed among studies for a given ACC isoform and a given herbicide might be attributed to differences in ACC assays, as shown by Shukla et al. (1997a), this is likely not the case for comparisons performed within a given study, and this is certainly not the reason why cytosolic homomeric ACC isoforms are consistently found to be less sensitive by several orders of magnitude to APPs and CHDs than the rather similar homomeric plastidic isoforms from grasses (Table 2). It has been proposed elsewhere that the efficacy of a given ACC-inhibiting herbicide toward a given homomeric ACC isoform will depend on how well the inhibitor molecule fits inside the CT active site cavity (Délye et al. 2005). For instance, the $S(-)$ enantiomer of ACC molecules cannot adopt a conformation fitting inside the CT active site because of the methyl group on the chiral carbon, whereas the $R(+)$ enantiomer can, which is the basis for the $R(+) / S(-)$ selectivity of APP enantiomers (Zhang et al. 2004b). A likely explanation for the differences in sensitivity observed among homomeric ACC isoforms is thus the occurrence of differences in the access to, and the fit inside, the CT active site cavity of ACC inhibitor molecules. In this respect, it should be mentioned that the plastidic ACC from the parasitic protozoan Toxoplasma gondii is rather sensitive to APPs but not to CHDs (Table 2), which enabled the proposition that APPderived molecules could be used in treatments for some human and animal protozoa-related diseases (Jelenska et al. 2002). Apart from a few exceptions, the selectivity of APPs and CHDs against grasses is therefore based on the differ- 


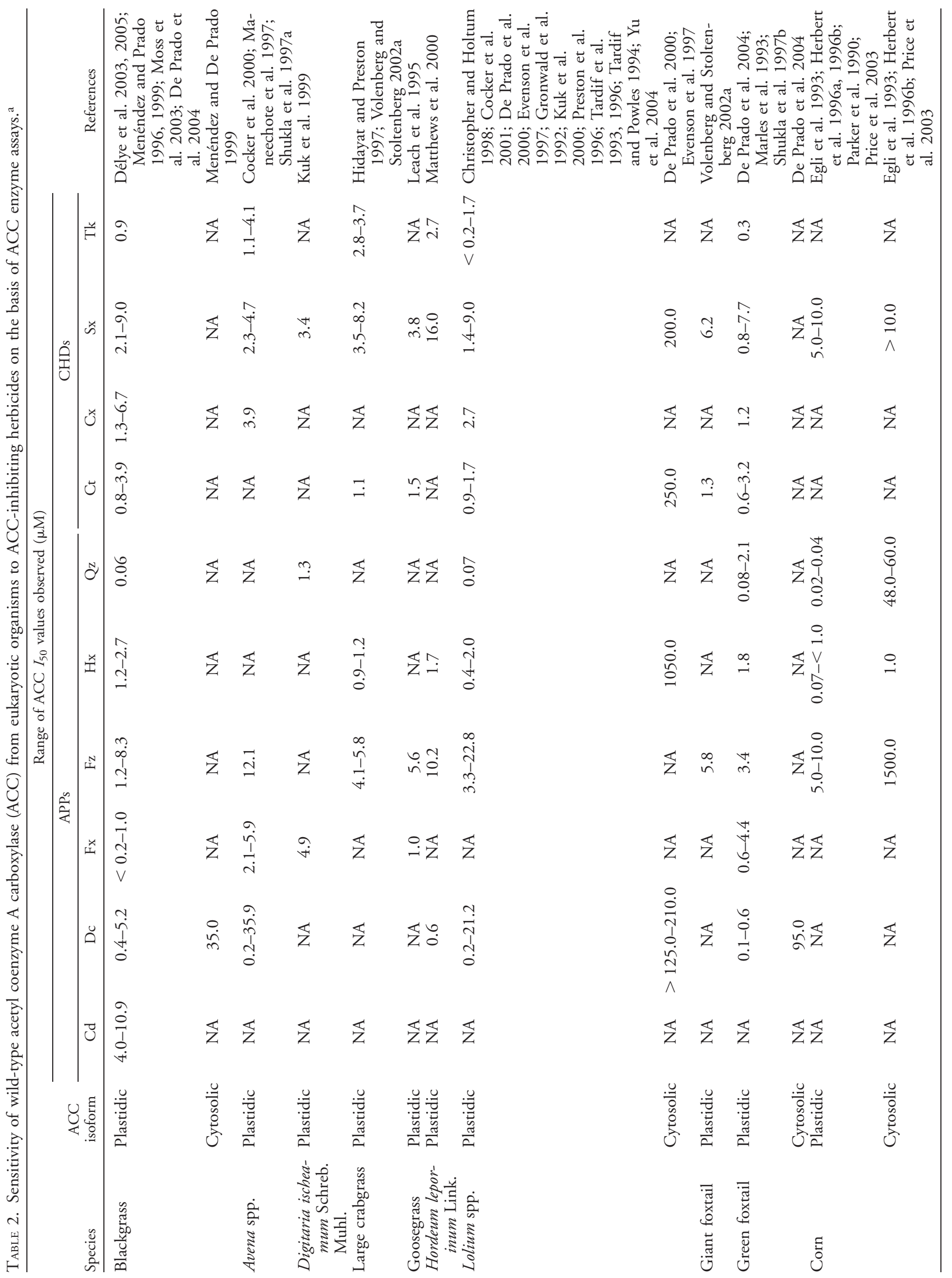

732 - Weed Science 53, September-October 2005 


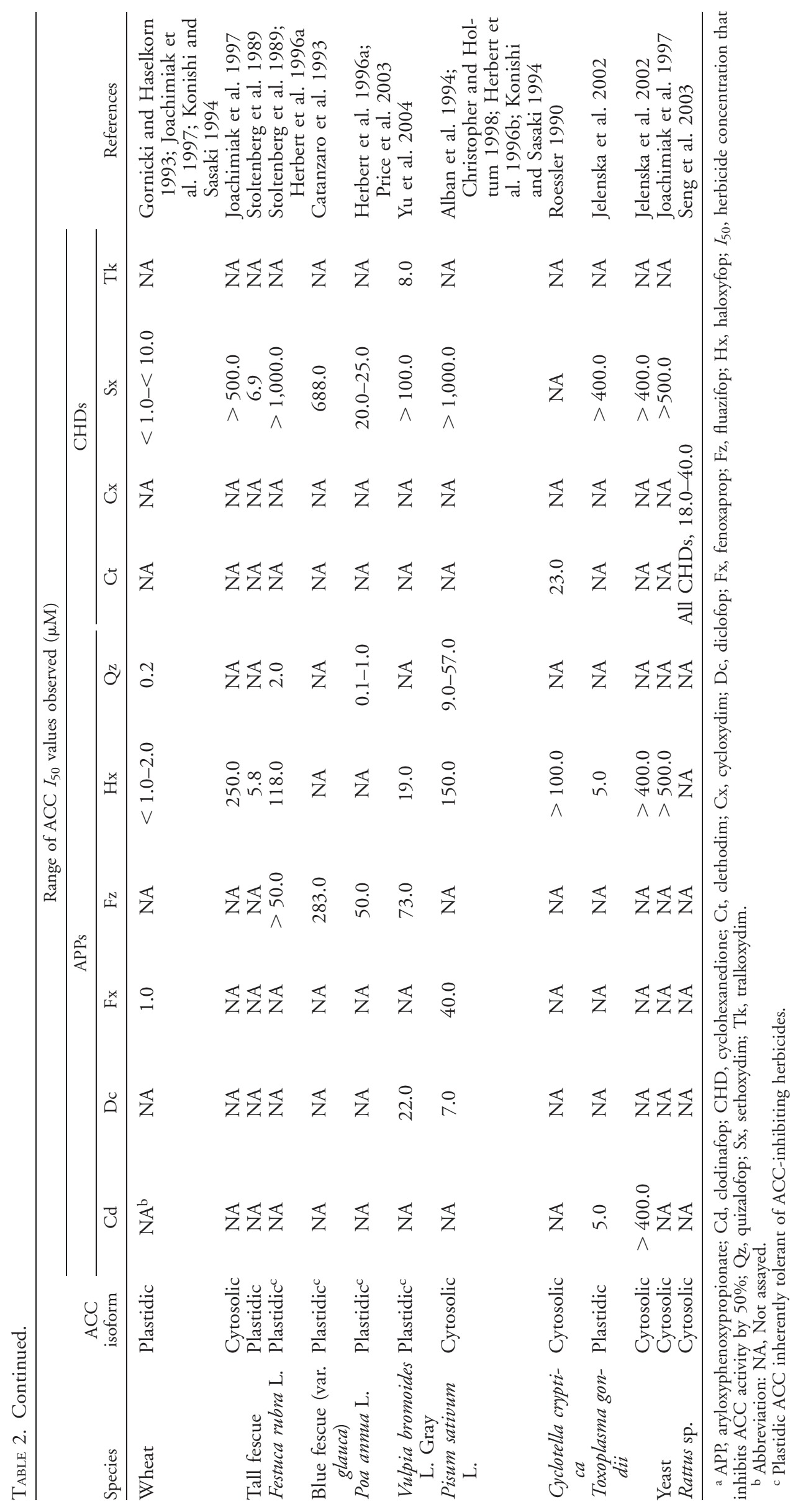


ences in sensitivity existing among plastidic homomeric ACC and other ACC isoforms.

\section{Selectivity on the Basis of Herbicide Metabolism}

Grass crops such as wheat, corn (Zea mays L.), or rice (Orysa sativa L.) contain plastidic homomeric ACC isoforms with sensitivity to APPs and CHDs similar to that of plastidic ACCs from grass weeds (Table 2). However, ACCinhibiting herbicides are used to control weeds in these crops (e.g., the APPs fenoxaprop and diclofop or the CHD tralkoxydim). The selectivity of CHDs is solely based on the capacity of the grass crop to rapidly metabolize the herbicide in question into inactive products. APPs are applied as relatively inactive carboxylic acid esters (e.g., fenoxaprop-ethyl, diclofop-methyl) to enhance their penetration in plants (Devine and Shimabukuro 1994). The ester bond is hydrolyzed by esterase activity to release the acid, herbicidally active form of APPs. An esterase involved in the activation of APPs has recently been fully characterized in blackgrass (Cummins and Edwards 2004). The selectivity of APPs against grass weeds is based on a more rapid hydrolysis of the ester to the active acid form of APPs in grass weeds (Cummins and Edwards 2004; Hill et al. 1978; Jeffcoat and Harries 1973) and a faster metabolism of the active herbicide in grass crops (Shimabukuro et al. 1979).

The capacity to metabolize ACC-inhibiting herbicides can be either inherent to the grass crop or triggered by safeners. Safeners are chemicals exhibiting a high botanical and chemical specificity. They suppress the phytotoxic effects of herbicides toward crop plants without altering their activity against weeds. Safeners have recently been reviewed in detail elsewhere (Davies and Caseley 1999; Hatzios and Burgos 2004). They trigger genes or metabolic pathways with a role in general plant response to stress in a manner similar to other abiotic or biotic factors like pathogens, drought, or heat shock (Hatzios and Burgos 2004). In particular, safeners stimulate glutathione- $S$-transferase (GST), cytochrome P450 (pigment absorbing at $450 \mathrm{~nm}$ )-dependent monooxygenase (CYP), and glucosyl transferase activities degrading herbicides. The mechanisms of herbicide degradation will be discussed in the "Molecular basis of resistance to ACC inhibitors" section because they also endow grass weed resistance to ACC-inhibiting herbicides. It should however be noted that different enzymes can be involved in degradation of herbicides in the same family. For example, in wheat, constitutively expressed CYP activity metabolizes the APP herbicide diclofop and the CHD tralkoxydim via aryl hydroxylation and hydroxylation of the $p$ methyl group, respectively (Hadfield et al. 1994; McFadden et al. 1989), whereas a safener-induced GST isoform detoxifies the APP fenoxaprop via glutathione conjugation (Tal et al. 1993). It should be noted that not all ACC-inhibiting herbicides are selective toward grass crops. Poor metabolism by the crop or lack of a suitable safener prevents some APPs (e.g., haloxyfop) or CHDs (e.g., clethodim or sethoxydim) to be applied in grass crops.

Safeners also enhance the elimination of herbicide metabolites via vacuole sequestration or incorporation into cell walls (Hatzios and Burgos 2004). Although it is proposed that most of the safener action has to do with gene transcription enhancement, very little is known to date about the perception and transduction mechanisms involved in the protective action of safeners.

\section{Molecular Basis of Resistance to ACC Inhibitors}

The high number of herbicide resistance cases reported thus far (Heap 2004) and the information passed around by researchers and herbicide manufacturers should not obliterate the fact that, to be effective, herbicides must be applied properly on weed populations. The efficacy of ACC-inhibiting herbicides against grass weeds could vary substantially depending on the growth stage of the targeted weeds (Milner et al. 2001). The "in-field" susceptibility to ACC inhibitors of grass weeds at a growth stage theoretically susceptible to ACC-inhibiting herbicides depends on the physiology of the weeds during and after herbicide application, and that physiology depends in turn on environmental factors such as the weather (Collings et al. 2003).

The selection exerted by highly effective herbicides results in weed populations that are no longer controlled by the herbicide doses originally applied. This phenomenon is known as "resistance to herbicides." When properly applied, herbicides inhibiting ACC kill $>95 \%$ of sensitive plants in grass weed populations (Foster et al. 1993). They have consequently been used repetitively for years on vast cropping surfaces as the sole way of controlling grass weeds, which rapidly lead to the selection of grass weed populations able to withstand field-rate doses of ACC-inhibiting herbicides (Devine and Shimabukuro 1994). Resistance to herbicides has been defined in several ways, the most satisfactory possibly being "the inheritable ability of a weed not to be controlled by an herbicide" (Gressel 1990, p. 174). This definition encompasses both mechanisms that reduce the sensitivity of weeds to herbicides and that modify ecological traits so that weeds are enabled to dodge herbicides. The following terms will be used hereafter: cross-resistance for resistance to several herbicides endowed by a single gene, multiple resistance for resistance to several herbicides endowed by more than one gene, and tolerance (Anonymous 1998) for species that intrinsically cannot be controlled by ACC-inhibiting herbicides. Resistance factors (RFs) are ratios between concentrations of an herbicide that exert a similar effect on resistant and sensitive plants, respectively.

Mechanisms of resistance to ACC-inhibiting herbicides can be divided into two categories: ACC-related and metabolism-based. These two categories of mechanisms are also involved in selectivity of ACC-inhibiting herbicides toward crops, as discussed previously. Numerous studies, mostly based on biological and enzymological data, have been conducted on a number of grass weed species in which plants resistant to ACC-inhibiting herbicides have been identified. Both target-related and metabolism-based mechanisms underlying resistance to APPs and CHDs are best and most thoroughly understood in a single grass weed species, blackgrass.

\section{ACC-Related Mechanisms of Resistance}

These mechanisms confer resistance to ACC-inhibiting herbicides by either rendering plastidic ACC activity resistant to the herbicide action or by increasing the herbicide- 
sensitive plastidic ACC activity, thus making up for the inhibiting action of the herbicide.

\section{Mutations within Homomeric Plastidic ACC}

Since the early 1990s, a number of biochemical studies have contributed to show that homomeric plastidic ACC isoforms with altered sensitivity to APPs, CHDs, or both are a mechanism of resistance to these herbicides that is widespread among and within grass species (Table 3). However, the identification of mutations involved in altered sensitivity was not achieved until recently. The five variable amino acids with a role in sensitivity to ACC-inhibiting herbicides identified so far are listed in Table 4. An updatable version of this table will be maintained at the International Survey of Herbicide Resistant Weeds Web site (www.weedscience.org). Researchers are encouraged to add new data to this list.

Although highly conserved among species, homomeric ACC sequences differ in length (Table 1) because of nonconserved additions or deletions and because of the presence of the dual-targeting peptide in plastidic isoforms (Figure 2; Table 1). This leads to a variation in the position of amino acid residues of interest among species. Furthermore, only partial ACC sequences are available for several grass species (e.g., wild oat [Avena fatua L.], Lolium sp.). Blackgrass is the grass for which ACC has been most thoroughly studied on a biochemical and molecular biology basis (Délye et al. 2002a, 2002b, 2003, 2005; Menéndez and De Prado 1999; Moss et al. 2003; Price et al. 2004) and in which the highest number of ACC mutations has been identified (Table 4). To avoid confusion in future ACC studies, it is proposed that ACC amino acid substitutions be referenced with the corresponding position in blackgrass plastidic ACC (EMBL/ Genbank/DDBJ accession AJ310767), as in this review (Table 4).

Caution should be taken when comparing RFs derived from herbicide concentrations that inhibit ACC activity by $50 \%$ ( $I_{50}$ values), as discussed in the "Selectivity of ACCinhibiting herbicides toward crop plants" section. However, results of published studies enable a rough separation of three groups of cross-resistance patterns conferred by mutant plastidic ACC isoforms (Table 3). One group of mutant ACC isoforms confers a very high RF to the CHD sethoxydim, but much lower RFs to other CHDs and to APPs. This cross-resistance pattern has been associated in four grass species with an isoleucine (Ile) to leucine (Leu) substitution at position 1781 that has been selected by sethoxydim alone or in association with APPs (Tables 3 and 4). A second group of mutant ACC isoforms that has been selected by APPs only confers high RFs to APPs but low RFs or no resistance at all to CHDs (Table 3). This cross-resistance pattern is conferred by a tryptophan (Trp) to cysteine (Cys), an Ile to asparagine (Asn), or a glycine (Gly) to alanine (Ala) substitution at positions 2027, 2041, or 2096, respectively, in blackgrass (Tables 3 and 4). It should be noted that an Ile to valine (Val) substitution at position 2041 did not confer a high RF to the APP clodinafop, in contrast with the Ile to Asn substitution at position 2041 (Table 4; Délye et al. 2003). In a third group, mutant ACC isoforms selected by APPs or CHDs confer high RFs to all APPs and CHDs assayed (Table 3). In blackgrass, this cross-resistance pattern is associated with an aspartic acid (Asp) to Gly sub- stitution at position 2078 (Tables 3 and 4). The last subdivision in Table 3 contains mutant ACCs with various cross-resistance patterns that did not fit elsewhere. These patterns are highly diverse and are likely associated with mutations distinct from those already known.

All five variable amino acid residues associated with resistance to ACC-inhibiting herbicides are located within the active site cavity of the ACC CT domain (Délye et al. 2005). From tridimensional models derived from yeast homomeric cytosolic ACC, only the substitution at position 2041 directly interfered with herbicide binding. Given the likely tight fit of ACC inhibitor molecules within the cavity of the CT active site (see the section "Selectivity of ACCinhibiting herbicides toward crop plants"), it has been proposed that the other four mutations cause resistance by hampering herbicide access to its binding site, by altering the spatial shape of the herbicide binding site via small allosteric changes, or by both mechanisms (Délye et al. 2005). That such a subtle change as the Ile to Leu substitution at position 1781 has such a drastic effect on the sensitivity to sethoxydim (Table 3) clearly illustrates the tight fit of the herbicide within the CT active site cavity. Although the cavity of the CT active site is constituted by almost equal contributors from two distinct regions of the CT domain (Zhang et al. 2003), one determinant for herbicide resistance (residue 1781) occurred in a region of highly conserved three-dimensional structure, whereas the four other known to date were clustered in a more variable region encompassing amino acid positions 2027 to 2096. It is probable that additional, yet unknown, mutations exist there that confer altered sensitivity to ACC inhibitors.

\section{Homomeric Plastidic ACC Inherently Tolerant to ACC-Inhibiting Herbicides}

Several grass species are tolerant of ACC-inhibiting herbicides because a plastidic homomeric ACC intrinsically displaying a sensitivity to these molecules that is in the range of what is usually observed for cytosolic homomeric ACCs (Table 2). Tolerant plastidic ACCs are found at least in the Festuca, Poa, and Vulpia genera (Table 2). The molecular basis for tolerance at the enzyme level is unknown. Furthermore, not all species within a genus may contain a tolerant homomeric plastidic ACC: red fescue (Festuca rubra L.) and blue fescue (Festuca ovina var. glauca Lam. Koch.) contain a tolerant plastidic ACC, whereas the closely related species tall fescue (Festuca arundinacea Shreb.) does not (Catanzaro et al. 1993; Stoltenberg et al. 1989). Grasses tolerant to ACC-inhibiting herbicides are not major weeds. However, Lolium spp. are major weeds that are normally sensitive to ACC-inhibiting herbicides but readily hybridize with Festuca species (Morgan et al. 2001). Such hybridizations might result in the introgression of tolerant plastidic ACCs from Festuca sp. into Lolium sp., as has been suspected in Italian Lolium spp. populations (Dinelli et al. 2004).

\section{Increase in Homomeric Plastidic ACC Activity}

This atypical resistance mechanism has only been reported in johnsongrass (Sorghum halepense L.; Bradley et al. 2001). The authors observed similar $I_{50}$ values for the plastidic ACC isoforms from resistant and sensitive plants but higher plastidic ACC-specific activity in resistant plants. 


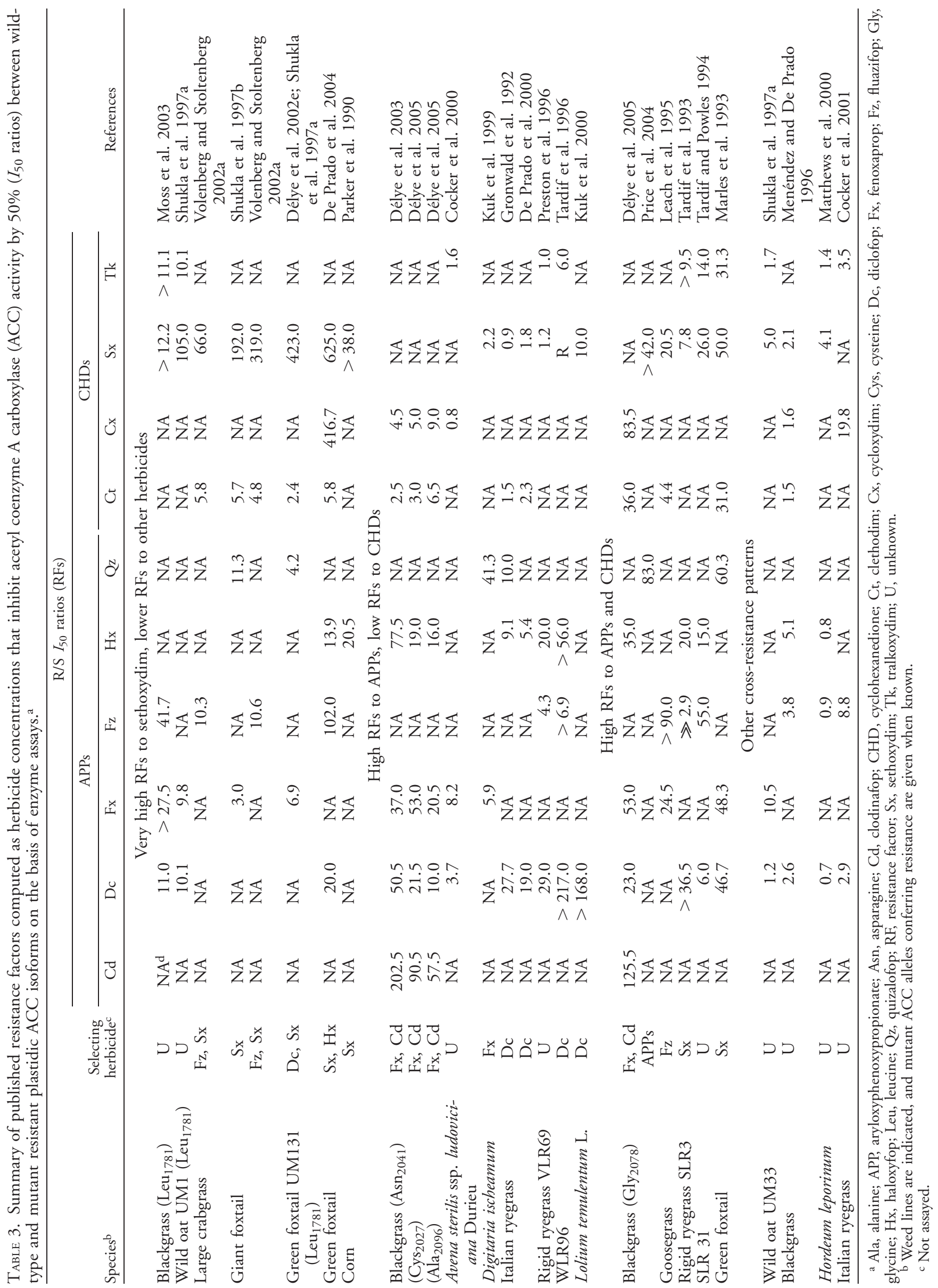




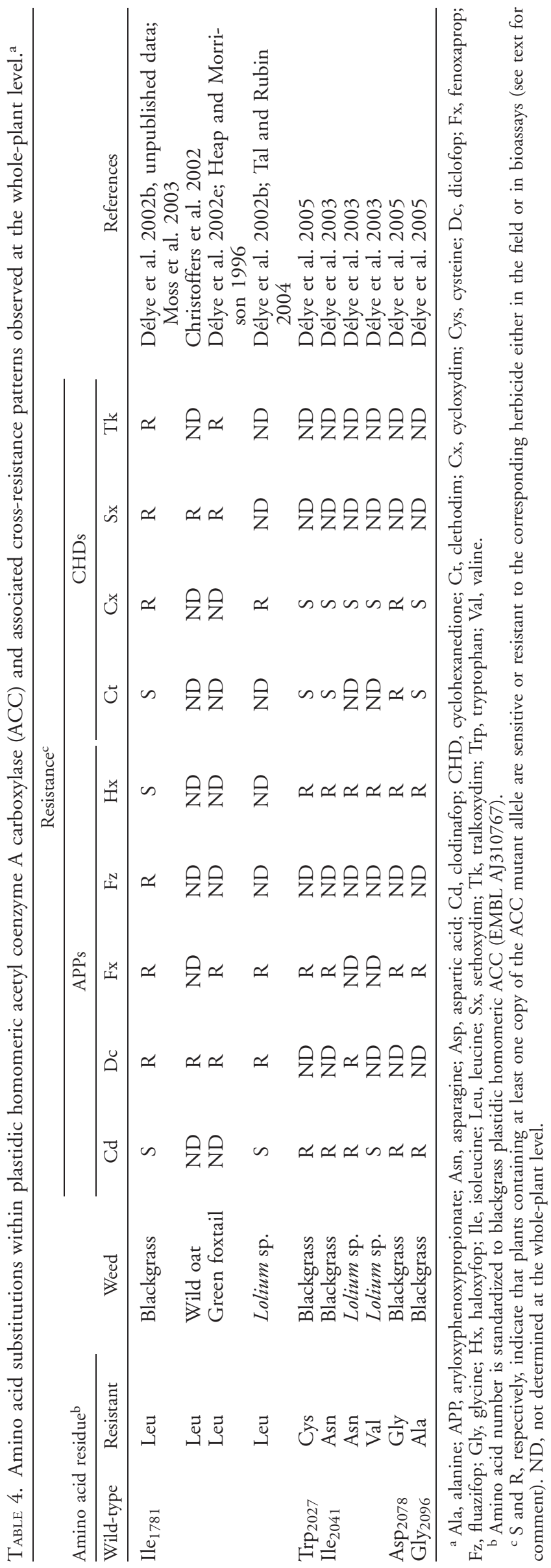

Their interpretation was an overproduction of the plastidic ACC isoform in the resistant plants. However, given that the specific activity of the plastidic ACC per milligram of ACC protein in resistant plants was threefold higher than that in sensitive plants, it seems more likely that resistance to ACC-inhibiting herbicides in johnsongrass was due to the presence of a plastidic ACC isoform with increased intrinsic catalytic activity. The molecular basis for this increase in ACC activity remains unknown.

\section{Metabolism-Based Mechanisms of Resistance}

Herbicides are external factors that apply powerful stresses on plants. As a consequence, they trigger plant pathways of general response to stress. Metabolism-based detoxification of herbicides in grasses can thus be viewed as a deviation of enzymes normally involved in the proceeding of endogenous products so as to (1) prevent a concentration in active herbicide molecules sufficient to cause metabolic damage to be reached at the target site, or (2) make up for the herbicide deleterious effects, or both. Such enzymes enable grass crops to withstand field applications of ACC-inhibiting herbicides. They also exist in grass weeds. Variation in their regulation, specificity, or both confers metabolism-based resistance to ACC-inhibiting herbicides in grass weeds.

Metabolism modifies the chemistry of herbicide molecules, and therefore their properties. The quicker a plant is capable of altering herbicide molecules, the more resistant it is to these herbicides. Metabolism of herbicides can be described as a three-phase process (for review, see Kreuz et al. 1996; Van Eerd et al. 2003). In a first phase, the herbicide is generally transformed into a more water-soluble and less toxic molecule via oxidation, hydrolysis, or reduction. Notable exceptions for this are APP esters that are activated in their acidic phytotoxic form in the first phase of their metabolism pathway, as discussed in the "Selectivity of ACC-inhibiting herbicides toward crop plants" section. A second phase involves conjugation of an herbicide or its metabolite to the tripeptide glutathione ( $\gamma$-Glu-Cys-Gly), a sugar, or an amino acid, which further decreases the toxicity of the parent molecule. In a third phase, metabolites from the second phase are further conjugated and eliminated by exportation to the vacuoles or incorporation into the cell walls.

A variety of enzymes are involved in herbicide metabolism (Kreuz et al. 1996; Van Eerd et al. 2003). Among the enzymes involved in the first phase of herbicide metabolism, CYPs have been shown to be involved in metabolism-based resistance to ACC-inhibiting herbicides. CYPs are heme proteins belonging to multigenic families. They mostly catalyze the $\mathrm{NADPH}_{2}$-dependent mono-oxygenation of a variety of molecules. The reader is referred to reviews for an overview of the gene organization, the structure and the functions of CYPs (Werck-Reichhart and Feyereisen 2000), and the role of CYPs in herbicide metabolism (Kreuz et al. 1996; Werck-Reichhart et al. 2000). Although an increase in CYP activity has been demonstrated to play a role in resistance to ACC-inhibiting herbicides in a number of studies that used various CYP inhibitors (Table 5), no CYP gene endowing resistance to ACC-inhibiting herbicides has been characterized to date. The use of CYP inhibitors will block the first phase of herbicide metabolism, thus inhibiting the provision of herbicide metabolites for further me- 


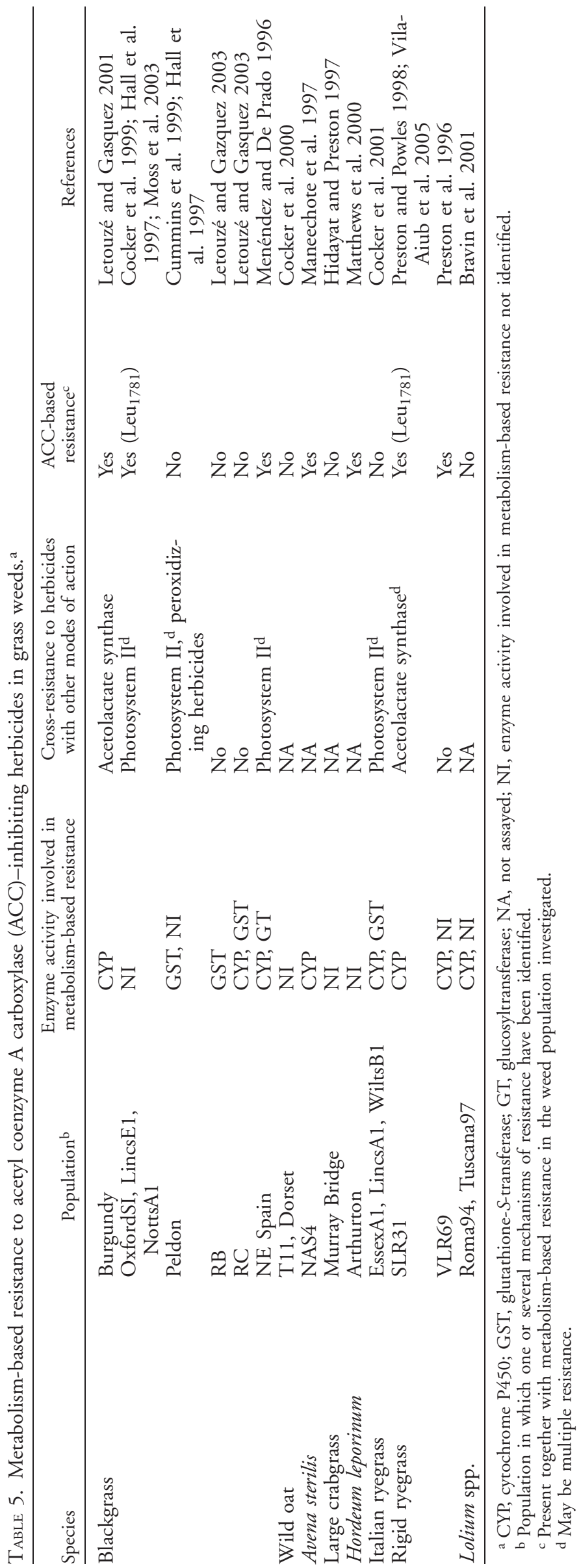

tabolism reactions. Such studies thus demonstrate that CYPs are involved in metabolism-based resistance to ACC-inhibiting herbicides, but not that they are solely responsible for this resistance.

Among the enzymes involved in the second phase of herbicide metabolism, glucosyltransferases (GTs) and GSTs have been shown to be involved in metabolism-based resistance to ACC-inhibiting herbicides. GTs catalyze the $O$ glucosylation of CYP-hydroxyled molecules. GT activity is well known in grass crops such as wheat (Van Eerd et al. 2003). The role of GT activity in resistance to ACC-inhibiting herbicides has been shown solely in the blackgrass population A. myosuroides 'Peldon', in which resistance was shown to be partly the result of a constitutive increase in both CYP and GT activities (Brazier et al. 2002). GSTs catalyze the ATP-dependent conjugation of first-phase herbicide metabolites to glutathione. Like CYPs, GSTs belong to multigenic families. Active GST enzymes are mostly homo- or heterodimers, with various dimer combinations coexisting in plants. The gene organization and the structure and functions of GSTs have recently been reviewed elsewhere (Frova 2003), as has their role in metabolism-based resistance to herbicides in weeds (Reade et al. 2004). It has been shown in blackgrass that an increase in GST activity could be associated with a decrease in sensitivity to APPs (Milner et al. 2001; Reade and Cobb 2002). Interestingly, at least a part of this increase in GST activity observed in resistant blackgrass plants was due to the constitutive overexpression of a gene encoding a GST isoform that did not metabolize APPs. Instead, this isoform protected blackgrass cells from the cytotoxicity of APPs resulting from the production of hydroperoxides issued from the disruption of fatty acid biosynthesis by reducing these hydroperoxides to the corresponding, less toxic alcohols via a secondary glutathione-peroxidase activity (Cummins et al. 1999).

A number of genes are clearly involved in metabolismbased resistance to ACC-inhibiting herbicides, which renders their study fairly complicated. Besides, cross-resistance patterns associated with metabolism-based resistance are quite unpredictable, and the range of herbicide molecules concerned is broader than in the case of ACC-related resistance. Indeed, in several weed species, CYP or GST activities have been associated with resistance to ACC- and acetolactate synthase-inhibiting herbicides, ACC- and photosystem II-inhibiting herbicides (Preston 2004), or ACC-inhibiting and peroxidizing herbicides (Cummins et al. 1999; Table 5). However, metabolism-based cross-resistance to herbicides with different modes of action has so far been clearly demonstrated only in the case of ACC-inhibiting and peroxidizing herbicides (Cummins et al. 1999) and in one case for ACC- and acetolactate synthase-inhibiting herbicides (Letouzé and Gasquez 2001). Other studies merely proved that inhibition of a given CYP or GST activity restored or increased sensitivity to herbicides with different target enzymes. The inhibitors used were not specific for a single CYP or GST isoform, and a given CYP or GST activity can be a result of several distinct isoenzymes. Thus, these studies did not prove that resistance to herbicides with different target sites was due to a single CYP or GST gene, thereby not excluding the possibility for multiple resistance. The range of herbicides concerned with metabolism-based multiple or cross-resistance being rather unpredictable, manag- 
ing weed populations resistant to ACC-inhibiting herbicides because of enhanced herbicide metabolism by switching to herbicides with a different mode of action could prove tricky.

\section{Membrane Repolarization: Not a Resistance Mechanism}

Recovery of transmembrane potential has been reported in several cases as a mechanism of resistance to ACC-inhibiting herbicides (Vila-Aiub et al. 2003; for a review, see Holtum et al. 1994) in the context of the hypothetical interaction of these herbicides with a putative binding site on cell membranes that was discussed in the section "Structure and mode of action of ACC-inhibiting herbicides". However, as discussed there, it seems more than likely that the membrane repolarization observed in some resistant plants is a secondary consequence of a resistance mechanism rather than the mechanism itself (Shukla et al. 1997a). In particular, repolarization might result from transmembrane pumps excreting herbicide metabolites toward vacuoles or cell walls.

\section{Evolution of Resistance to ACC-Inhibiting Herbicides}

The development of herbicide resistance in weeds is an evolutionary process. Herbicide treatments of weed populations result in the selection of any gene(s) conferring individual plants the capacity to withstand herbicides at the rate used in the field and to reproduce successfully thereafter. Under herbicide selection, the genetic composition of the weed population changes so that the frequency of resistance genes increases. The population genetic factors influencing the evolution of herbicide resistance in weed populations have been reviewed elsewhere (Jasieniuk et al. 1996). Prominent among them are genetic control of resistance, the initial frequency of resistance genes in weed populations, inheritance of resistance, the fitness penalty associated with resistance genes, and gene flows among weed populations. As discussed hereafter, not very much is known about these factors in the case of resistance to ACC-inhibiting herbicides.

\section{Genetic Control of Resistance}

\section{Identification of Resistance}

Before studying the evolution of resistance in a weed species, it is necessary to ensure that this resistance does exist. This requires assessing herbicide effects under standardized conditions that enables good herbicide efficacy. A number of bioassays based on a differential response of resistant and sensitive plants to discriminating doses of ACC-inhibiting herbicides have been developed for this purpose (Beckie et al. 2000; Boutsalis 2001; Letouzé and Gasquez 1999; Retrum and Forcella 2002; Tal et al. 2000). These assays, based either on seed (e.g., Letouzé and Gasquez 1999) or the whole plant (e.g., Boutsalis 2001), enable the detection of a phenotype (i.e., herbicide-resistant) but do not provide data about the gene(s) endowing it.

It should be mentioned here that, depending on the bioassay used, cross-resistance patterns observed at the enzyme and at the plant levels might not be identical. For instance, plants containing mutant ACC isoforms with substitutions at positions 2027, 2041, and 2096 that displayed low RFs to CHDs at the enzyme level (Table 3) were found to be sensitive to CHDs in a seedling-based bioassay (Délye et al. 2003,2005 ). In such bioassays, weed seeds are germinating in an herbicide solution, which makes the plants face herbicide doses much higher than is expected to occur in field conditions. It is therefore possible that these plants could survive field rates of CHDs.

\section{Discriminating among Resistance Mechanisms}

Unraveling the genetic control of resistance to ACC-inhibiting herbicides is a prerequisite to understanding its evolution. Of particular importance is the necessity to discriminate between ACC-based and metabolism-based resistance at the plant level because ACC-based resistance will be selected solely by ACC-inhibiting herbicides, whereas metabolism-based resistance might be selected by herbicides with alternative target sites (see the section "Metabolism-based mechanisms of resistance"). In the absence of a quick and simple ACC enzyme assay, it has been proposed that the $\mathrm{CHD}$ sethoxydim can be used routinely as an indicator of the presence of ACC-based resistance because it is not exposed to metabolism-based resistance (Moss et al. 2003). However, three out of the five mutant ACC alleles identified so far appear to confer resistance to APPs only (Table 4), which renders sethoxydim a rather unreliable indicator of ACC-based resistance. ACC-based resistance is expressed in pollen, whereas metabolism-based resistance is not (Letouzé and Gasquez 2000; Richter and Powles 1993). A pollenbased bioassay thus seems a more reliable routine test to identify ACC-based resistance. Alternatively, polymerase chain reaction (PCR)-based assays enabling specific detection of resistant ACC alleles have been developed in blackgrass (Délye et al. 2002a, 2002b, 2003, 2005), Lolium sp. (Délye et al. 2002b; Tal and Rubin 2004), or green foxtail (Délye et al. 2002c) and could be adapted to other grass weed species provided that resistant ACC alleles are characterized. Conversely, one enzyme-linked immunosorbent assay (ELISA) that allows the detection of metabolism-based resistance from enhanced GST activity has been developed in blackgrass (Reade and Cobb 2002).

\section{Coexistence of Various Resistance Genes within a Single Weed Population/Plant}

It appears that in most cases in which the cause of resistance has been identified, resistance to ACC-inhibiting herbicides is the result of a mutant plastidic ACC (Tables 3 and 5). The prevalence of ACC-based resistance cases might partly be a consequence of the relatively straightforward identification of resistant ACC isoforms by biochemical or molecular methods, whereas that of the diverse enzymes underlying metabolism-based resistance is more problematic. This means that, when ACC-based resistance is identified, metabolism-based resistance could be present as well, although not identified. In the case of ACC-related resistance, different resistant ACC alleles have been found in a single blackgrass population, and even in a single plant (Délye et al. 2004a, 2005). Besides, where the mechanisms of resistance to ACC-inhibiting herbicides have been investigated in detail, it was found that ACC-related and metabolism- 
based resistance mechanisms can coexist within a single weed population (Table 5) or even a single weed plant (Letouzé and Gasquez 2001; Maneechote et al. 1997; Vila-Aiub et al. 2005). At least in weeds such as blackgrass or Lolium spp., in which it has been studied extensively, resistance to ACC-inhibiting herbicides thus appears to be a complex trait, governed by probably more than five mutant ACC alleles and a certainly higher number of metabolism genes. In this respect the broadly used terms "resistant population" and "resistant biotype" are misleading. Indeed, resistant populations/biotypes are often treated as homogeneous entities, although they contain individuals that could be resistant to a given herbicide by different mechanisms, thus displaying heterogeneous cross-resistance patterns and resistance factors. Furthermore, resistant populations/biotypes most often contain a certain proportion of sensitive plants. Given the complexity of the genetic control of resistance to ACC-inhibiting herbicides, resistance should rather be considered at the level of the plant. Population studies should consider the frequency of resistant plants and the variety of RFs or resistance mechanisms present within a weed population.

\section{Mutation to Resistance and Initial Frequency of Resistant Plants in a Weed Population}

The gene encoding plastidic ACC has been proposed to be under purifying selection because the vast majority of nucleotide substitutions observed there were silent or synonymous (Délye et al. 2004b). This suggested that not any amino acid replacement, and therefore not any mutation conferring resistance to ACC-inhibiting herbicides, can occur and be maintained in the field. This is consistent with the vital metabolic role of plastidic ACC. However, although it has been shown that $\mathrm{Leu}_{1781}$ and $\mathrm{Asn}_{2041}$ mutant ACC alleles each evolved from several distinct, independent origins in blackgrass (Délye et al. 2004a, 2004b), there is no published data about the frequency of occurrence of mutations in the gene encoding plastidic ACC. The same is true for any mutation at loci conferring resistance to ACCinhibiting herbicides. The frequency of weed plants resistant to ACC-inhibiting herbicides before their initial application is poorly known as well. This is mostly because of the huge number of plants that must be screened in an unsprayed population to obtain reliable estimates of this frequency. The initial frequency of weed plants resistant to ACC-inhibiting herbicides has only been estimated in Australian rigid ryegrass (Lolium rigidum Gaud.) populations and U.S. wild oat populations, where it fluctuated between 3\% and $<0.2 \%$, depending on the population (Matthews and Powles 1992; Mengistu et al. 2003). The number and the nature of the gene(s) endowing resistance in these populations were not determined.

\section{Inheritance of Resistance}

The gene encoding plastidic ACC and the genes involved in metabolism-based resistance are nuclear, meaning they can be propagated both by seed and pollen. ACC-based resistance was found to be dominant over sensitivity in wild oat (Kibite et al. 1995), blackgrass (Letouzé and Gasquez 2001), and foxtail millet [Setaria italica (L.) Beauv.; Wang and Darmency 1998]. In both studies, a single discriminat- ing dose of herbicide was used. When a range of herbicide doses was used, ACC-based resistance was found to be dominant over sensitivity in foxtail millet (Wang and Darmency 1997) and partially dominant over sensitivity in corn (Marshall et al. 1992; Parker et al. 1990), wild oat (Murray et al. 1995, 1996), and rigid ryegrass (Tal et al. 2004; Tardif et al. 1996). At herbicide doses much higher than field rate, ACC-based resistance was also found to be partially dominant over sensitivity in Italian ryegrass (Lolium multiflorum Lam.; Betts et al. 1992) and giant foxtail (Setaria faberi Herrm.; Volenberg and Stoltenberg 2002b). In wild oat, ACC-based resistance was dominant over sensitivity at low herbicide doses but partially dominant at higher doses (Seefeld et al. 1998). Partial dominance of ACC-based resistance over sensitivity along a range of herbicide doses seems consistent with the ACC-inhibiting mode of action (see the section "Structure and mode of action of ACC-inhibiting herbicides"). The point is, however, that ACC-based resistance is dominant at field rates (herbicide doses selecting for resistance genes in weed populations). As a consequence, plants homozygous and heterozygous for ACC-based resistance all survive field-rate treatments, although the effects of these treatments on their respective seed production has not been compared to date. Dominance of metabolismbased resistance to ACC-inhibiting herbicides has only been studied in blackgrass populations in which a CYP-based resistance was shown to be dominant over sensitivity at a single, discriminating herbicide dose (Letouzé and Gasquez 2001). It can thus be expected that most genes endowing resistance to ACC-based herbicides confer a resistance that is dominant over sensitivity at the herbicide field rate.

\section{Herbicide Selective Pressure and Fitness Cost}

At field rate, ACC-inhibiting herbicides display a killing rate for sensitive plants ranging from 95 to 97\% (Foster et al. 1993). Any gene enabling an individual plant to survive herbicide application will thus strongly be selected for. However, the particular herbicide(s) exerting selective pressure is not a reliable predictor for the resistance $\operatorname{pattern}(s)$ that will be selected. As an example, the five resistant mutant ACC alleles identified in blackgrass confer distinct cross-resistance patterns (Table 4), although they have essentially been selected for by the APPs fenoxaprop, clodinafop, or both (Délye et al. 2004a, 2005). Similarly, resistance to CHDs in wild oat has been selected by both APPs and CHDs, and not solely by CHDs (Légère et al. 2000). When other than ACC-based resistance mechanisms are involved, the relationship between selecting herbicides and selected resistance patterns is still more unpredictable. For instance, the use of APPs can result in the selection of multiple or cross-resistance to herbicides with other sites of action (Cummins et al. 1999; Friesen et al. 2000; Letouzé and Gasquez 2001; Preston 2004).

After selection, the outcome of resistance genes in weed populations depends on their pleiotropic effects on the fitness of individual plants in the absence of herbicide. Fitness can be defined as survival and reproductive success in a given environment. Determining the relative fitness of resistant and sensitive plants is therefore crucial to understand the evolution of the genetic structure of weed populations. Fitness studies require the comparison of major traits in the life cycle of weeds (e.g., seed germination, vegetative growth 
rate, seed production) between resistant and sensitive plants and the assessment of the ecological consequences in the field of the differences observed. Ideally, comparisons should be performed in a range of environmental conditions between plants containing or not containing a clearly identified resistance gene and otherwise displaying close genetic backgrounds. Few studies provided data about the fitness of plants resistant to ACC-inhibiting herbicides. No differences were found in growth or seed production between resistant and sensitive plants in giant foxtail and large crabgrass [ $\mathrm{Dig}$ itaria sanguinalis (L.) Scop.; Wiederholt and Stoltenberg 1996a, 1996b]. However, neither study is really informative because the gene(s) endowing resistance was not identified, and resistant and sensitive plants were issued from distinct populations. This is also true for a study comparing resistant and sensitive plants respectively originating from two distinct populations of goosegrass (Eleusine indica L. Gaertn.; Marshall et al. 1994). The "weakly inheritable" resistant phenotype studied there might have been under polygenic control, and the higher resource allocation toward seed production observed in the resistant plants could not be clearly associated with resistance. In a study comparing the germination of rigid ryegrass seeds from individual plants of population SLR31 that were sensitive or resistant because of either increased CYP activity or both a resistant mutant $\mathrm{Leu}_{1781}$ ACC allele and increased CYP activity, seeds from the latter type of plants were found to require light and higher temperatures to germinate (Vila-Aiub et al. 2005). This enabled the authors to propose that the plants from this particular population could be controlled in the field by seed burial via shallow cultivation so as to maximize their fitness penalty.

Different fitness penalties can be associated with different resistance genes and even with different mutant alleles of a gene encoding an herbicide target enzyme (Roux et al. 2004). Similarly, different fitness penalties can be associated with the various mutant ACC alleles conferring herbicide resistance (Table 4). Indeed, investigators in a study conducted on nine populations of blackgrass suspected that fenoxaprop selected $\mathrm{Leu}_{1781}$ ACC alleles rather than $\mathrm{Asn}_{2041}$ alleles (Délye et al. 2004a). Because both types of alleles confer resistance to fenoxaprop (Table 4), it was proposed that a higher fitness penalty might be associated with $\mathrm{Asn}_{2041}$ ACC alleles (Délye et al. 2004a). This hypothesis must be checked by more extensive studies. It is consistent with the $\mathrm{Ile}_{1781}$ to Leu substitution most often observed among species (Table 4), suggesting that limited or no fitness penalty might be associated with this particular resistant ACC allele. Conversely, a strong reduction in ACC activity that could have consequences on fitness has been observed in blackgrass for $\mathrm{Cys}_{2027}$ and Gly 2078 ACC alleles (Délye et al. 2005). Constitutive, metabolism-based resistance like that observed in blackgrass (Brazier et al. 2002; Cummins et al. 1999) is also likely to result in a fitness penalty, but there is no published study to date to check this point.

\section{Weed Mating Systems and Gene Flows among Populations}

Resistance to ACC-inhibiting herbicides has developed in highly selfing species such as green foxtail, as well as in highly outcrossing species such as blackgrass. However, the mating system of species is of importance because a variety of resistance genes will accumulate more rapidly in individual plants in outcrossing species. Similarly, gene flow by pollen or seeds among populations that evolved different resistance genes might be crucial for the evolution of resistance at the species level. The relative contribution of pollen and seeds to gene flow within and among populations clearly depends on the species considered. In the mostly selfing species wild oat, resistance gene flows occur among weed patches and distinct fields. The large-sized seeds of Avena spp. seem a more efficient vector for resistance genes than pollen (Andrews et al. 1998; Cavan et al. 1998a; Murray et al. 2002); however, cross-pollination appeared to occur both between and within the two species, thus likely playing a role in the evolution and spread of resistance to ACC-inhibiting herbicides (Cavan et al. 1998a). In the mostly outcrossing species blackgrass, gene flows both among weed patches in a field and among distant fields were estimated to be quite low (Cavan et al. 1998b; Délye et al. 2004a, 2004b). Nevertheless, molecular data suggested that longdistance gene flows existed until recently and might still exist among blackgrass populations (Délye et al. 2004a, 2004b). It can be proposed that the small seeds of blackgrass contaminating cereal crop or grass forage crop seed batches would mediate these gene flows. Data obtained from Avena spp. and blackgrass suggest a major role of seeds in the propagation of resistance to ACC-inhibiting herbicides in these species. Large-scale studies need to be conducted before this point is definitely proved.

\section{Is the Evolution of Resistance to ACC-Inhibiting Herbicides Predictable?}

From the data obtained in blackgrass, Avena spp. and Lolium spp., resistance to ACC-inhibiting herbicides appears to be a complex trait under an oligogenic or polygenic control. Resistance genes are mostly dominant at herbicide field rates and can accumulate in a single plant. On the other hand, spraying programs are most often designed at the field level. At the level of the range of a weed species, spraying programs thus create a mosaic of selective pressures that select for a likely large variety of resistance genes, with associated cross-resistance patterns that are little predictable. Lo$\mathrm{cal}$ weed populations adapted to local spraying programs will thus emerge. The emerging picture is that of resistance to ACC-inhibiting herbicides that likely evolves following a "patchy" frame, as observed in wild oat (Beckie et al. 1999, 2002) and suspected in blackgrass (Délye et al. 2004a). Besides, as suggested by a recent survey conducted in wild oat (Mengistu et al. 2003), the selective pressure of ACC-inhibiting herbicides, if constantly applied, would likely result in the rapid (Délye et al. 2004b) selection of many resistance genes, leading to an increasingly complex genetic control of resistance and, in fine, to the emergence of local, highly fit, resistant phenotypes that might also be resistant to herbicides with alternative modes of action. All this renders a prediction for the global evolution of resistance unachievable.

\section{What Now?}

Herbicides strongly contribute to secure yield and are indispensable in traditional, mechanized crop farming. How- 
ever, the increase in costs to bring new products on the market (Cobb and Kirkwood 2000), the growing public concern of the use of pesticides, and the lack of herbicides under development with new modes of action, combined with the development of resistant weed populations, represent a growing threat to the most effective way for farmers to control weeds. Three research topics appear relevant with regard to ACC-inhibiting herbicides.

\section{Slowing the Development of Resistance}

An obvious way of delaying the increase in frequency of resistant plants in a weed population is not to use herbicides selecting for resistance to control this population. To do so, quick resistance diagnosis tests such as the PCR- or ELISAbased assays mentioned in the "Genetic control of resistance" section are potentially useful resistance management tools because their rapidity enables the avoidance of spraying herbicides that will further select resistance during the growing season when resistance is detected. Field studies showed that breaking the life cycle of weeds, and consequently reducing the abundance of weed populations, is an efficient way of slowing up the development of resistance to ACCinhibiting herbicides. This can be achieved by various cultural methods, such as ploughing or incorporation of perennial forage crops, that reduce weed abundance and facilitate less frequent herbicide use, as demonstrated in blackgrass (Chauvel et al. 2001) and wild oat (Beckie et al. 2004). When ecological differences between resistant and sensitive plants are known, cultural methods can also be devised so as to maximize the fitness penalty in resistant plants, as proposed in rigid ryegrass (Vila-Aiub et al. 2005).

Alternate use of herbicides with different target sites is predicted by models to significantly reduce the selection for resistance (Jasieniuk et al. 1996), as theorized for blackgrass and wild oat (Cavan et al. 2000, 2001). Another possibility is spraying tank-mixed herbicides with different modes of action (Diggle et al. 2003). Such tactics must however consider broad-spectrum, multiple, or cross-resistance from metabolism-based resistance mechanisms occurring at the level of the population or the plant. With application of tankmixed herbicides, the possible antagonism between herbicides with different modes of action must also be considered (Barnes and Oliver 2004).

\section{Developing New ACC-Inhibiting Herbicides}

APPs and CHDs are very useful selective graminicides. In this respect, new molecules inhibiting the enzyme activity of all homomeric plastidic ACC isoforms, either sensitive or resistant to APPs, CHDs, or both, would have obvious commercial appeal. Derivatives of APP and CHD molecules have been found to be good leads for developing such molecules (Rendina et al. 1990; Shukla et al. 2004). Substrate analogs, such as the one proposed as a basis for the development of antibacterial agents targeting heteromeric ACC (Levert and Waldrop 2002), might also be of interest. Another approach involves high-throughput, random screening of molecules for anti-ACC activity. In the absence of a microassay for ACC activity, a pilot screen that uses antibody mimics of homomeric ACCs to identify such molecules has been developed (Webb and Hall 2002). In contrast to this approach, the availability of the tridimensional structure of the CT domain of homomeric ACC (Zhang et al. 2003) should enable the rational design of ACC inhibitors. The $\mathrm{CT}$ domain in plastidic homomeric ACC is under purifying selection (Délye et al. 2004b). Thus, the probability of simultaneous occurrence of mutations conferring resistance to APPs and CHDs and to molecules with a distinct binding site inside the CT active site cavity is expected to be extremely low. Bipiperidylcarboxamide derivatives are potent inhibitors of mammal homomeric ACC isoforms (Harwood et al. 2003). A tridimensional model study showed that one of these compounds bound at a site not overlapping the binding site for APPs in the yeast homomeric ACC CT domain (Zhang et al. 2004a), thus making bipiperidylcarboxamide derivatives potential candidates for the development of new ACC-inhibiting herbicides. However, tridimensional models for the homomeric ACC CT domain are based on the structure of yeast homomeric ACC (Zhang et al. 2003). As discussed in the "Structure and mode of action of ACC-inhibiting herbicides" section, the binding mode of APPs and CHDs to grass plastidic homomeric ACC likely differs in detail from what is observed in yeast. A tridimensional structure of the CT domain of a grass plastidic homomeric CT domain is thus needed for an effective rational design of new ACC-inhibiting herbicides.

\section{Unraveling Metabolism-Based Resistance}

Molecular biology recently provided for a rather thorough comprehension of the mechanisms of ACC-based resistance to herbicides. More data is now needed about the ecological consequences (e.g., fitness penalty) of ACC-based resistance. However, ACC-based resistance is only one facet of resistance to ACC-inhibiting herbicides. A complete understanding of this phenomenon implies studying metabolism-based resistance. In contrast to ACC-based resistance, our knowledge of metabolism-based resistance is rather poor. Metabolism-based resistance is likely widespread. It could have heavy deleterious consequences for weed control, primarily because of the broad range of present and future herbicide molecules that can be affected. It seems therefore clear that the new challenge for weed scientists dealing with resistance to herbicides in general is to unravel the basis and assess the ecological consequences of metabolism-based resistance in weeds. Given the diversity of mechanisms involved, this task will certainly prove harder to complete than understanding target-based resistance mechanisms. In the near future, weed genomics (Basu et al. 2004) and molecular ecotoxicology (Sandermann 2004) might well provide the keys to metabolism-based resistance to herbicides, as did "standard" molecular biology for target-based resistance.

\section{Literature Cited}

Alban, C., P. Baldet, and R. Douce. 1994. Localization and characterization of two structurally different forms of acetyl-CoA carboxylase in young pea leaves, of which one is sensitive to aryloxyphenoxypropionate herbicides. Biochem J. 300:557-565.

Andrews, T. S., I. N. Morrison, and G. A. Penner. 1998. Monitoring the spread of ACCase inhibitor resistance among wild oat (Avena fatua) patches using AFLP analysis. Weed Sci. 46:196-199.

Anonymous. 1998. "Herbicide resistance" and "herbicide tolerance" defined. Weed Technol. 12:789.

Anonymous. 2004. Herbicide resistance action committee. www. plantprotection.org/HRAC. Accessed October 11, 2004.

Ashton, A. R., C.L.D. Jenkins, and P. R. Whitfeld. 1994. Molecular cloning 
of two different cDNAs for maize acetyl CoA carboxylase. Plant Mol. Biol. 24:35-49.

Barnes, J. W. and L. R. Oliver. 2004. Cloransulam antagonizes annual grass control with aryloxyphenoxypropionate graminicides but not cyclohexanediones. Weed Technol. 18:763-772.

Basu, C., M. D. Halfhill, T. C. Mueller, and C. N. Stewart, Jr. 2004. Weed genomics: new tools to understand weed biology. Trends Plant Sci. 9: 391-398.

Beckie, H. J., L. M. Hall, S. Meers, J. J. Laslo, and F. C. Stevenson. 2004. Management practices influencing herbicide resistance in wild oat. Weed Technol. 18:853-859.

Beckie, H. J., I. M. Heap, R. J. Smeda, and L. M. Hall. 2000. Screening for herbicide resistance in weeds. Weed Technol. 14:428-445.

Beckie, H. J., A. G. Thomas, A. Légère, D. J. Kelner, R. C. Van Acker, and S. Meers. 1999. Nature, occurrence, and cost of herbicide-resistant wild oat (Avena fatua) in small-grain production areas. Weed Technol. 13:612-625.

Beckie, H. J., A. G. Thomas, and F. C. Stevenson. 2002. Survey of herbicide-resistant wild oat (Avena fatua) in two townships in Saskatchewan. Can. J. Plant Sci. 82:463-471.

Betts, K. J., N. J. Ehlke, D. L. Wyse, J. W. Gronwald, and D. A. Somers. 1992. Mechanism of inheritance of diclofop resistance in italian ryegrass (Lolium multiflorum). Weed Sci. 40:184-189.

Boutsalis, P. 2001. Syngenta Quick-Test: a rapid whole-plant test for herbicide resistance. Weed Technol. 15:257-263.

Bradley, K. W., J. Wu, K. K. Hatzios, and E. S. Hagood, Jr. 2001. The mechanism of resistance to aryloxyphenoxypropionate and cyclohexanedione herbicides in a johnsongrass biotype. Weed Sci. 49:477-484.

Bravin, F., G. Zanin, and C. Preston. 2001. Resistance to diclofop-methyl in two Lolium spp. populations from Italy: studies on the mechanism of resistance. Weed Res. 41:461-473.

Brazier, M., D. J. Cole, and R. Edwards. 2002. O-glycosyltransferase activities towards phenolic natural products and xenobiotics in wheat and herbicide-resistant and herbicide-susceptible black-grass (Alopecurus myosuroides). Phytochemistry 59:149-156.

Burton, J. D., J. W. Gronwald, R. A. Keith, D. A. Somers, B. G. Gegenbach, and D. L. Wyse. 1991. Kinetics of inhibition of acetyl-coenzyme A carboxylase by sethoxydim and haloxyfop. Pestic. Biochem. Physiol. 39:100-109.

Burton, J. D., J. W. Gronwald, D. A. Somers, J. A. Connelly, B. G. Gegenbach, and D. L. Wyse. 1987. Inhibition of plant acetyl-coenzyme A carboxylase by the herbicides sethoxydim and haloxyfop. Biochem. Biophys. Res. Commun. 148:1039-1044.

Catanzaro, C. J., J. D. Burton, and W. A. Skroch. 1993. Graminicide resistance of acetyl-CoA carboxylase from ornamental grasses. Pestic. Biochem. Physiol. 45:147-153.

Cavan, G., P. Biss, and S. R. Moss. 1998a. Herbicide resistance and gene flow in wild-oats (Avena fatua and Avena sterilis ssp. ludoviciana). Ann. Appl. Biol. 133:207-217.

Cavan, G., P. Biss, and S. R. Moss. 1998b. Localized origins of herbicide resistance in Alopecurus myosuroides. Weed Res. 38:239-245.

Cavan, G., J. Cussans, and S. Moss. 2000. Modelling different cultivation and herbicide strategies for their effect on herbicide resistance in $\mathrm{Al}$ opecurus myosuroides. Weed Res. 40:561-568.

Cavan, G., J. Cussans, and S. Moss. 2001. Managing the risks of herbicide resistance in wild oat. Weed Sci. 49:236-240.

Chauvel, B., J.-P. Guillemin, N. Colbach, and J. Gasquez. 2001. Evaluation of cropping systems for management of herbicide-resistant populations of blackgrass (Alopecurus myosuroides Huds.). Crop Prot. 20:127-137.

Christoffers, M. J., M. L. Berg, and C. G. Messersmith. 2002. An isoleucine to leucine mutation in acetyl-CoA carboxylase confers herbicide resistance in wild oat. Genome 45:1049-1056.

Christopher, J. T. and J.A.M. Holtum. 1998. The dicotyledonous species Erodium moschatum (L) L'Hér. ex. Aiton is sensitive to haloxyfop herbicide due to herbicide-sensitive acetyl-coenzyme A carboxylase. Planta 207:275-279.

Christopher, J. T. and J.A.M. Holtum. 2000. Dicotyledons lacking the multisubunit form of acetyl coenzyme A carboxylase may be restricted to the family Geraniaceae. Aust. J. Plant Physiol. 27:845-850.

Cobb, A. H. and R. C. Kirkwood. 2000. Challenges for herbicide development. Pages 1-24 in A. H. Cobb and R. C. Kirkwood, eds. Herbicides and Their Mechanisms of Action. Sheffield, UK: Sheffield Academic Press.

Cocker, K. M., J.O.D. Coleman, A. M. Blair, J. H. Clarke, and S. R. Moss. 2000. Biochemical mechanisms of cross-resistance to aryloxyphenox- ypropionate and cyclohexanedione herbicides in populations of Avena spp. Weed Res. 40:323-334.

Cocker, K. M., S. R. Moss, and J.O.D. Coleman. 1999. Multiple mechanisms of resistance to fenaxoprop-P-ethyl in United Kingdom and other European populations of herbicide-resistant Alopecurus myosuroides (black-grass). Pestic. Biochem. Physiol. 65:169-180.

Cocker, K. M., D. S. Northcroft, J.O.D. Coleman, and S. R. Moss. 2001. Resistance to ACCase-inhibiting herbicides and isoproturon in UK populations of Lolium multiflorum: mechanisms of resistance and implications for control. Pest Manag. Sci. 57:587-597.

Collings, L. V., A. M. Blair, A. P. Gay, C. J. Dyer, and N. Mackay. 2003. The effect of weather factors on the performance of herbicides to control Alopecurus myosuroides in winter wheat. Weed Res. 43:146153.

Cummins, I., D. J. Cole, and R. Edwards. 1999. A role for glutathione transferases functioning as glutathione peroxidases in resistance to multiple herbicides in black-grass. Plant J. 18:285-292.

Cummins, I. and R. Edwards. 2004. Purification and cloning of an esterase from the weed black-grass (Alopecurus myosuroides), which bioactivates aryloxyphenoxypropionate herbicides. Plant J. 39:894-904.

Davies, J. and J. C. Caseley. 1999. Herbicide safeners: a review. Pestic. Sci. 55:1043-1058.

Délye, C., É. Calmès, and A. Matéjicek. 2002a. SNP markers for blackgrass (Alopecurus myosuroides Huds.) genotypes resistant to acetyl CoAcarboxylase inhibiting herbicides. Theor. Appl. Genet. 104:11141120 .

Délye, C., A. Matéjicek, and J. Gasquez. 2002b. PCR-based detection of resistance to acetyl-CoA carboxylase-inhibiting herbicides in blackgrass (Alopecurus myosuroides Huds) and ryegrass (Lolium rigidum Gaud). Pest Manag. Sci. 58:474-478.

Délye, C., C. Straub, A. Matéjicek, and S. Michel. 2004a. Multiple origins for black-grass (Alopecurus myosuroides Huds.) target site-based resistance to herbicides inhibiting acetyl-CoA carboxylase. Pest Manag. Sci. 60:35-41.

Délye, C., C. Straub, S. Michel, and V. Le Corre. 2004b. Nucleotide variability at the acetyl-coenzyme A carboxylase gene and the signature of herbicide selection in the grass weed Alopecurus myosuroides (Huds.). Mol. Biol. Evol. 21:884-892.

Délye, C., T. Wang, and H. Darmency. 2002c. An isoleucine-leucine substitution in chloroplastic acetyl-Co A carboxylase from green foxtail (Setaria viridis L. Beauv.) is responsible for resistance to the cyclohexanedione herbicide sethoxydim. Planta 214:421-427.

Délye, C., X.-Q. Zhang, C. Chalopin, S. Michel, and S. B. Powles. 2003. An isoleucine residue within the carboxyl-transferase domain of multidomain acetyl-CoA carboxylase is a major determinant of sensitivity to aryloxyphenoxypropionate but not to cyclohexanedione inhibitors. Plant Physiol. 132:1716-1723.

Délye, C., X.-Q. Zhang, S. Michel, A. Matéjicek, and S. B. Powles. 2005. Molecular bases for sensitivity to acetyl-coenzyme A carboxylase inhibitors in black-grass. Plant Physiol. 137:794-806.

De Prado, R., J. González-Gutiérrez, J. Menéndez, J. Gasquez, J. W. Gronwald, and R. Giménez-Espinosa. 2000. Resistance to acetyl CoA carboxylase-inhibiting herbicides in Lolium multiflorum. Weed Sci. 48: 311-318.

De Prado, R., M. D. Osuna, and A. J. Fisher. 2004. Resistance to ACCase inhibitor herbicides in a green foxtail (Setaria viridis) biotype in Europe. Weed Sci. 52:506-512.

Devine, M. D. and R. H. Shimabukuro. 1994. Resistance to acetyl coenzyme A carboxylase inhibiting herbicides. Pages 141-169 in S. B. Powles and J.A.M. Holtum, eds. Herbicide Resistance in Plants. Boca Raton, FL: CRC Press.

Diggle, A. J., P. B. Neve, and F. P. Smith. 2003. Herbicides used in combination can reduce the probability of herbicide resistance in finite weed populations. Weed Res. 43:371-382.

Dinelli, G., A. Bonetti, I. Marotti, M. Minelli, and P. Catizone. 2004. Characterization of Italian populations of Lolium spp. resistant and susceptible to diclofop by inter simple sequence repeat. Weed Sci. 52: 554-563.

Di Tomaso, J. M. 1994. Evidence against a direct membrane effect in the mechanism of action of graminicides. Weed Sci. 42:302-309.

Egli, M. A., B. G. Gegenbach, J. W. Gronwald, D. A. Somers, and D. L. Wyse. 1993. Characterization of maize acetyl-coenzyme A carboxylase. Plant Physiol. 101:499-506.

Evenson, K. J., J. W. Gronwald, and D. L. Wyse. 1997. Isoforms of acetylcoenzyme A carboxylase in Lolium multiflorum. Plant Physiol. Biochem. 35:265-272. 
Faris, J., A. Sirikhachornkit, R. Haselkorn, B. Gill, and P. Gornicki. 2001. Chromosome mapping and phylogenetic analysis of the cytosolic acetyl-CoA carboxylase loci in wheat. Mol. Biol. Evol. 18:1720-1733.

Focke, M., E. Gieringer, S. Schwan, L. Jänsch, S. Binder, and H.-P. Braun. 2003. Fatty acid biosynthesis in mitochondria of grasses: malonylcoenzyme A is generated by mitochondrial-localized acetyl-coenzyme A carboxylase. Plant Physiol. 133:875-884.

Foster, D. K., P. Ward, and R. T. Hewson. 1993. Selective grass-weed control in wheat and barley based on the safener fenchlorazole-ethyl. Pages 1267-1272 in British Crop Protection Council, ed. Proceedings of the Brighton Crop Protection Conference-Weeds. Surrey, Great Britain, British Crop Protection Council.

Friesen, L. F., T. L. Jones, R. C. Van Hacker, and I. N. Morrison. 2000. Identification of Avena fatua populations resistant to imazamethabenz, flamprop and fenoxaprop-P. Weed Sci. 48:532-540.

Frova, C. 2003. The plant glutathione transferase gene family: genomic structure, functions, expression and evolution. Physiol. Plant. 119: 469-479.

Gerwick, B. C., L. A. Jackson, J. Handly, N. R. Gray, and J. W. Russell. 1988. Pre-emergence and post-emergence activities of the $(R)$ and $(S)$ enantiomers of haloxyfop. Weed Sci. 36:453-456.

Gornicki, P., J. Faris, I. King, J. Podkowinski, B. Gill, and R. Haselkorn. 1997. Plastid-localised acetyl-CoA carboxylase of bread wheat is encoded by a single gene on each of the three ancestral chromosome sets. Proc. Natl. Acad. Sci. USA 94:14179-14184.

Gornicki, P. and R. Haselkorn. 1993. Wheat acetyl-CoA carboxylase. Plant Mol. Biol. 22:547-552.

Gressel, J. 1990. Need herbicide resistance have evolved? Generalizations from around the world. Pages 173-184 in J. W. Heap, ed. Proceedings of the 9th Australian Weeds Conference. Adelaide, Australia: Crop Science Society of South Australia.

Gronwald, J. W., C. V. Eberlein, K. J. Betts, R. J. Baerg, N. J. Ehlke, and D. L. Wyse. 1992. Mechanism of diclofop resistance in an Italian ryegrass (Lolium multiflorum Lam.) biotype. Pestic. Biochem. Physiol. 44:126-139.

Hadfield, S. T., A. Wilson, S. F. Kuet, and R. Mason. 1994. The metabolism of tralkoxydim in field-grown spring wheat and maize plant cell suspension culture. Pestic. Sci. 40:193-200.

Hall, L. M., S. R. Moss, and S. B. Powles. 1997. Mechanisms of resistance to aryloxyphenoxypropionate herbicides in two resistant biotypes of Alopecurus myosuroides (blackgrass): herbicide metabolism as a crossresistance mechanism. Pestic. Biochem. Physiol. 57:87-98.

Harwood, J. L. 1988. Fatty acid metabolism. Annu. Rev. Plant Physiol. 39: $101-138$.

Harwood, J. H., Jr., S. F. Petras, L. D. Shelly, et al. 2003. Isozyme-nonselective $\mathrm{N}$-substituted bipiperidylcarboxamide acetyl-CoA carboxylase inhibitors reduce tissue malonyl-CoA concentrations, inhibit fatty acid synthesis, and increase fatty acid oxidation in cultured cells and in experimental animals. J. Biol. Chem. 278:37,099-37,111.

Hatzios, K. K. and N. R. Burgos. 2004. Metabolism-based herbicide resistance: regulation by safeners. Weed Sci. 52:454-467.

Heap, I. M. 2004. International survey of herbicide resistant weeds. www.weedresearch.com. Accessed December 7, 2004.

Heap, I. M. and I. N. Morrison. 1996. Resistance to aryloxyphenoxypropionate and cyclohexanedione herbicides in green foxtail (Setaria viridis). Weed Sci. 44:25-30.

Herbert, D., D. J. Cole, K. E. Pallett, and J. L. Harwood. 1996a. Susceptibilities of different test systems from maize (Zea mays), Poa annua and Festuca rubra to herbicides that inhibit the enzyme acetyl-coenzyme A carboxylase. Pestic. Biochem. Physiol. 55:129-139.

Herbert, D., L. J. Price, C. Alban, L. Dehaye, D. Job, D. J. Cole, K. E. Pallett, and J. L. Harwood. 1996b. Kinetic studies on two isoforms of acetyl-CoA carboxylase from maize leaves. Biochem. J. 318:9971006.

Hidayat, I. and C. Preston. 1997. Enhanced metabolism of fluazifop acid in a biotype of Digitaria sanguinalis resistant to the herbicide fluazifopp-butyl. Pestic. Biochem. Physiol. 57:137-146.

Hill, B. D., E. H. Stobbe, and B. L. Jones. 1978. Hydrolysis of the herbicide benzoylprop-ethyl by wild oat esterase. Weed Res. 18:149-154.

Holtum, J.A.M., R. E. Häusler, M. D. Devine, and S. B. Powles. 1994 Recovery of transmembrane potentials in plants resistant to aryloxyphenoxypropionate herbicides: a phenomenon awaiting explanation. Weed Sci. 42:293-301.

Huang, S., A. Sirikhachornkit, J. D. Faris, X. Su, B. S. Gill, R. Haselkorn, and P. Gornicki. 2002. Phylogenetic analysis of the acetyl-CoA car- boxylase and 3-phosphoglycerate kinase in wheat and other grasses. Plant Mol. Biol. 48:805-820.

Incledon, B. J. and J. C. Hall. 1997. Acetyl-coenzyme A carboxylase: quaternary structure and inhibition by graminicidal herbicides. Pestic. Biochem. Physiol. 57:255-271.

Jasieniuk, M., A. L. Brûlé-Babel, and I. N. Morrison. 1996. The evolution and genetics of herbicide resistance in weeds. Weed Sci. 44:176-193.

Jeffcoat, B. and W. N. Harries. 1973. Selectivity and mode of action of ethyl ( \pm$)-2-(N$-benzoyl-3,4-dichloroanilino)propionate in the control of Avena fatua in cereals. Pestic. Sci. 4:891-899.

Jelenska, J., A. Sirikhachornkit, R. Haselkorn, and P. Gornicki. 2002. The carboxyltransferase activity of the apicoplast acetyl-CoA carboxylase of Toxoplasma gondii is the target of aryloxyphenoxypropionate inhibitors. J. Biol. Chem. 277:23,208-23,215.

Joachimiak, M., G. Tevzadze, J. Podkowinski, R. Haselkorn, and P. Gornicki. 1997. Wheat cytosolic acetyl-CoA carboxylase complements an ACC1 null mutation in yeast. Proc. Natl. Acad. Sci. USA 94:99909995.

Kibite, S., K. N. Harker, and P. D. Brown. 1995. Inheritance of resistance to diclofop-methyl and fenoxaprop-p-ethyl in two Avena sativa $\times A$. fatua populations. Can. J. Plant Sci. 75:81-85.

Konishi, T. and Y. Sasaki. 1994. Compartimentalization of two forms of acetyl-CoA carboxylase in plants and the origin of their tolerance towards herbicides. Proc. Natl. Acad. Sci. USA 91:3598-3601.

Konishi, T., K. Shinohara, K. Yamada, and Y. Sasaki. 1996. Acetyl-CoA carboxylase in higher plants: most plants other than gramineae have both the prokaryotic and the eukaryotic forms of this enzyme. Plant Cell Physiol. 37:117-122.

Kreuz, K., R. Tommasini, and E. Martinoia. 1996. Old enzymes for a new job. Herbicide detoxification in plants. Plant Physiol. 111:349-353.

Kuk, Y.-I., N. R. Burgos, and R. E. Talbert. 2000. Cross- and multiple resistance of diclofop-resistant Lolium spp. Weed Sci. 48:412-419.

Kuk, Y.-I., J. Wu, J. F. Derr, and K. K. Hatzios. 1999. Mechanism of fenaxoprop resistance in an accession of smooth crabgrass (Digitaria ischaemum). Pestic. Biochem. Physiol. 64:112-123.

Leach, G. E., M. D. Devine, R. C. Kirkwood, and G. Marshall. 1995. Target enzyme-based resistance to acetyl-coenzyme A carboxylase inhibitors in Eleusine indica. Pestic. Biochem. Physiol. 51:129-136.

Légère, A., H. J. Beckie, F. C. Stevenson, and A. G. Thomas. 2000. Survey of management practices affecting the occurrence of wild oat (Avena fatua) resistance to acetyl-CoA carboxylase inhibitors. Weed Technol. 14:366-376.

Letouzé, A. and J. Gasquez. 1999. A rapid reliable test for screening aryloxyphenoxypropionic acid resistance within Alopecurus myosuroides and Lolium spp. populations. Weed Res. 39:37-48.

Letouzé, A. and J. Gasquez. 2000. A pollen test to detect ACCase targetsite resistance within Alopecurus myosuroides populations. Weed Res. 40:151-162.

Letouzé, A. and J. Gasquez. 2001. Inheritance of fenoxaprop-P-ethyl resistance in a blackgrass (Alopecurus myosuroides Huds.) population. Theor. Appl. Genet. 103:288-296.

Letouzé, A. and J. Gasquez. 2003. Enhanced activity of several herbicidedegrading enzymes: a suggested mechanism responsible for multiple resistance in black-grass (Alopecurus myosuroides Huds.). Agronomie 23:601-608.

Levert, K. L. and G. L. Waldrop. 2002. A bisubstrate analog inhibitor of the carboxyltransferase component of acetyl-CoA carboxylase. Biochem. Biophys. Res. Commun. 291:1213-1217.

Mallory-Smith, C. A. and E. J. Retzinger, Jr. 2003. Revised classification of herbicides by site of action for weed resistance management strategies. Weed Technol. 17:605-619.

Maneechote, C., C. Preston, and S. B. Powles. 1997. A diclofop-methylresistant Avena sterilis biotype with a herbicide-resistant acetyl-coenzyme A carboxylase and enhanced metabolism of diclofop-methyl. Pestic. Sci. 49:105-114.

Marles, M.A.S., M. D. Devine, and J. C. Hall. 1993. Herbicide resistance in Setaria viridis conferred by a less sensitive form of acetyl coenzyme A carboxylase. Pestic. Biochem. Physiol. 46:7-14.

Marshall, G., R. C. Kirkwood, and G. E. Leach. 1994. Comparative studies on graminicide-resistant and susceptible biotypes of Eleusine indica. Weed Res. 34:177-185.

Marshall, L. C., D. A. Somers, P. D. Dotray, B. G. Gegenbach, D. L. Wyse, and J. W. Gronwald. 1992. Allelic mutations in acetyl-coenzyme A carboxylase confer herbicide tolerance in maize. Theor. Appl. Genet. 83:435-442.

Matthews, N. and S. B. Powles. 1992. Aspects of the population dynamics 
of selection for herbicide resistance in Lolium rigidum (Gaud.). Proc. First Int. Weed Control Congr. 2:318-320.

Matthews, N., S. B. Powles, and C. Preston. 2000. Mechanisms of resistance to acetyl-coenzyme A carboxylase-inhibiting herbicides in a Hordeum leporinum population. Pest Manag. Sci. 56:441-447.

McFadden, J. J., D. S. Frear, and E. R. Mansager. 1989. Aryl hydroxylation of diclofop by a cytochrome P450 dependent monooxygenase from wheat. Pestic. Biochem. Physiol. 32:92-100.

Menéndez, J. and R. De Prado. 1996. Diclofop-methyl cross-resistance in a chlortoluron-resistant biotype of Alopecurus myosuroides. Pestic. Biochem. Physiol. 56:123-133.

Menéndez, J. and R. De Prado. 1999. Characterization of two acetyl-CoA carboxylase isoforms in diclofop-methyl-resistant and -susceptible biotypes of Alopecurus myosuroides. Pestic. Biochem. Physiol. 65:82-89.

Mengistu, L. W., C. G. Messersmith, and M. J. Christoffers. 2003. Diversity of herbicide resistance among wild oat sampled 36 years apart. Weed Sci. 51:764-773.

Milner, L. J., J.P.H. Reade, and A. H. Cobb. 2001. Developmental changes in gluthatione $S$-transferase activity in herbicide-resistant populations of Alopecurus myosuroides Huds (black-grass) in the field. Pest Manag. Sci. 57:1100-1106.

Morgan, W. G., I. P. King, S. Koch, J. A. Harper, and H. M. Thomas. 2001. Introgression of chromosomes of Festuca arundinacea var glaucescens into Lolium multiflorum revealed by genomic in situ hybridisation (GISH). Theor. Appl. Genet. 103:696-701.

Moss, S. R., K. M. Cocker, A. C. Brown, L. Hall, and L. M. Field. 2003. Characterisation of target-site resistance to ACCase-inhibiting herbicides in the weed Alopecurus myosuroides (black-grass). Pest Manag. Sci. 59:190-201.

Murray, B. G., A. L. Brûlé-Babel, and I. N. Morrison. 1996. Two distinct alleles encode for acetyl-CoA carboxylase inhibitor resistance in wild oat (Avena fatua). Weed Sci. 44:476-481.

Murray, B. G., I. N. Morrison, and A. L. Brûlé-Babel. 1995. Inheritance of acetyl-CoA carboxylase inhibitor resistance in wild oat (Avena fatua). Weed Sci. 43:233-238.

Murray, B. G., I. N. Morrison, and L. F. Friesen. 2002. Pollen-mediated gene flow in wild oat. Weed Sci. 50:321-325.

Nikolau, B. J., J. B. Ohlrogge, and E. S. Wurtele. 2003. Plant biotincontaining carboxylases. Arch. Biochem. Biophys. 414:211-222.

Nikolskaya, T., O. Zagnitko, G. Tevzadze, R. Haselkorn, and P. Gornicki. 1999. Herbicide sensitivity determinant of wheat plastid acetyl-CoA carboxylase is located in a 400-amino acid fragment of the carboxyltransferase domain. Proc. Natl. Acad. Sci. USA 96:14647-14651.

Parker, W. B., L. C. Marshall, J. D. Burton, D. A. Somers, D. L. Wyse, J. W. Gronwald, and B. G. Gegenbach. 1990. Dominant mutations causing alterations in acetyl-coenzyme A carboxylase confer tolerance to cyclohexanedione and aryloxyphenoxypropionate herbicides in maize. Proc. Natl. Acad. Sci. USA 87:7175-7179.

Peeters, N. and I. Small. 2001. Dual targeting to mitochondria and chloroplasts. Biochim. Biophys. Acta 1541:54-63.

Podkowinski, J., G. E. Sroga, R. Haselkorn, and P. Gornicki. 1996. Structure of a gene encoding a cytosolic acetyl-CoA carboxylase of hexaploid wheat. Proc. Natl. Acad. Sci. USA 93:1870-1874.

Preston, C. 2004. Herbicide resistance in weeds endowed by enhanced detoxification: complications for management. Weed Sci. 52:448-453.

Preston, C. and S. B. Powles. 1998. Amitrole inhibits diclofop metabolism and synergises diclofop-methyl in a diclofop-methyl-resistant biotype of Lolium rigidum. Pestic. Biochem. Physiol. 62:179-189.

Preston, C., F. J. Tardif, J. T. Christopher, and S. B. Powles. 1996. Multiple resistance to dissimilar herbicide chemistries in a biotype of Lolium rigidum due to enhanced activity of several herbicide degrading enzymes. Pestic. Biochem. Physiol. 54:123-134.

Price, L. J., D. Herbert, D. J. Cole, and J. L. Harwood. 2003. Use of plant cell cultures to study graminicide effects on lipid metabolism. Phytochemistry 63:533-541.

Price, L. J., S. R. Moss, D. J. Cole, and J. L. Harwood. 2004. Graminicide resistance in a blackgrass (Alopecurus myosuroides) population correlates with insensitivity of acetyl-CoA carboxylase. Plant Cell Environ. 27: $15-26$.

Ratterman, D. M. and N. E. Balke. 1988. Herbicidal disruption of proton gradient development and maintenance by plasmalemma and tonoplast vesicles from oat root. Pestic. Biochem. Physiol. 31:221-236.

Reade, J.P.H. and A. H. Cobb. 2002. New, quick tests for herbicide resistance in black-grass (Alopecurus myosuroides Huds) based on increased gluthatione $S$-transferase activity and abundance. Pest Manag. Sci. 58: $26-32$.
Reade, J.P.H., L. J. Milner, and A. H. Cobb. 2004. A role for gluthatione $S$-transferase in resistance to herbicides in grasses. Weed Sci. 52:468474.

Rendina, A. R., A. C. Craig-Kennard, J. D. Beaudoin, and M. K. Breen. 1990. Inhibition of acetyl-coenzyme A carboxylase by two classes of grass-selective herbicides. J. Agric. Food Chem. 38:1282-1287.

Rendina, A. R., J. M. Felts, J. D. Beaudoin, A. C. Craig-Kennard, L. L. Look, S. L. Paraskos, and J. A. Hagenah. 1988. Kinetics characterization, stereoselectivity, and species selectivity of the inhibition of plant acetyl-CoA carboxylase by the aryloxyphenoxypropionic acid grass herbicides. Arch. Biochem. Biophys. 265:219-225.

Retrum, J. and F. Forcella. 2002. Giant foxtail (Setaria faberi) seedling assay for resistance to sethoxydim. Weed Technol. 16:464-466.

Richter, J. and S. B. Powles. 1993. Pollen expression of herbicide target site resistance genes in annual ryegrass (Lolium rigidum). Plant Physiol. 102:1037-1041.

Roessler, P. G. 1990. Purification and characterization of acetyl-CoA carboxylase from the diatom Cyclotella cryptica. Plant Physiol. 92:73-78.

Roux, F., J. Gasquez, and X. Reboud. 2004. The dominance of the herbicide resistance cost in several Arabidopsis thaliana mutant lines. Genetics 166:449-460.

Sandermann, H., Jr. 2004. Molecular ecotoxicology of plants. Trends Plant Sci. 9:406-413

Sasaki, Y., T. Konishi, and Y. Nagano. 1995. The compartmentation of acetyl-coenzyme A carboxylase in plants. Plant Physiol. 108:445-449.

Sasaki, Y. and Y. Nagano. 2004. Plant acetyl-CoA carboxylase: structure, biosynthesis, regulation, and gene manipulation for plant breeding. Biosci. Biotechnol. Biochem. 68:1175-1184.

Secor, J., C. Cseke, and J. W. Owen. 1989. The discovery of the selective inhibition of acetyl-coenzyme A carboxylase activity by two classes of graminicides. Brighton Crop Prot. Conf. Weeds 3B:145-154.

Seefeldt, S. S., D. L. Hoffman, D. R. Gealy, and E. P. Fuerst. 1998. Inheritance of diclofop resistance in wild oat (Avena fatua L.) biotypes from the Willamette Valley of Oregon. Weed Sci. 46:170-175.

Seng, T. W., T. R. Skillman, N. Yang, and C. Hammond. 2003. Cyclohexanedione herbicides are inhibitors of rat heart acetyl-CoA carboxylase. Bioorg. Med. Chem. Lett. 13:3237-3242.

Shimabukuro, R. H., D. G. Davis, and B. L. Hoffer. 2001. The effect of diclofop-methyl and its antagonist, vitamin $\mathrm{E}$, on membrane lipids in oat (Avena sativa L.) and leafy spurge (Euphorbia esula L.). Pestic. Biochem. Physiol. 69:13-26.

Shimabukuro, R. H., W. C. Walsh, and R. A. Hoerauf. 1979. Metabolism and selectivity of diclofop-methyl in wild oat and wheat. J. Agric. Food Chem. 27:615-623.

Shukla, A., S. Dupont, and M. D. Devine. 1997a. Resistance to ACCaseinhibitor herbicides in wild oat: evidence for target site-based resistance in two biotypes from Canada. Pestic. Biochem. Physiol. 57:147155.

Shukla, A., G. E. Leach, and M. D. Devine. 1997b. High-level resistance to sethoxydim conferred by an alteration in the target enzyme, acetylCoA carboxylase, in Setaria faberi and Setaria viridis. Plant Physiol. Biochem. 35:803-807.

Shukla, A., C. Nycholat, M. V. Subramanian, R. J. Anderson, and M. D. Devine. 2004. Use of resistant ACCase mutants to screen for novel inhibitors against resistant and susceptible forms of ACCase from grass weeds. J. Agric. Food Chem. 52:5144-5150.

Stoltenberg, D. E., J. W. Gronwald, D. L. Wyse, J. D. Burton, D. A. Somers, and B. G. Gegenbach. 1989. Effect of sethoxydim and haloxyfop on acetyl-coenzyme A carboxylase activity in Festuca species. Weed Sci. 37:512-516.

Tardif, F. J., J.A.M. Holtum, and S. B. Powles. 1993. Occurrence of a herbicide-resistant acetyl-coenzyme A carboxylase mutant in annual ryegrass (Lolium rigidum) selected by sethoxydim. Planta 190:176181.

Tardif, F. J. and S. B. Powles. 1994. Herbicide multiple-resistance in a Lolium rigidum biotype is endowed by multiple mechanisms: isolation of a subset with resistant acetyl-CoA carboxylase. Physiol. Plant. 91: 488-494.

Tardif, F. J., C. Preston, J.A.M. Holtum, and S. B. Powles. 1996. Resistance to acetyl-coenzyme A carboxylase-inhibiting herbicides endowed by a single major gene encoding a resistant target site in a biotype of Lolium rigidum. Aust. J. Plant Physiol. 23:15-23.

Tal, A., E. Kotoula-Syka, and B. Rubin. 2000. Seed-bioassay to detect grass weeds resistant to acetyl coenzyme A carboxylase inhibiting herbicides. Crop Prot. 19:467-472.

Tal, A., M. L. Romano, G. R. Stephenson, A. L. Schwan, and J. C. Hall. 
1993. Glutathione conjugation: a detoxification pathway for fenoxaprop-ethyl in barley, crabgrass, oat and wheat. Pestic. Biochem. Physiol. 46:190-199.

Tal, A. and B. Rubin. 2004. Molecular characterization and inheritance of resistance to ACCase-inhibiting herbicides in Lolium rigidum. Pest Manag. Sci. 601013-1018.

Turner, J. A. and D. J. Pernich. 2002. Origin of enantiomeric selectivity in the aryloxyphenoxypropionic acid class of herbicidal acetyl coenzyme A carboxylase (ACCase) inhibitors. J. Agric. Food Chem. 50: 4554-4566.

Van Eerd, L. L., R. E. Hoagland, R. M. Zablotowicz, and J. C. Hall. 2003. Pesticide metabolism in plants and microorganisms. Weed Sci. 51: 472-495.

Vila-Aiub, M. M., C. M. Ghersa, and M. Carceller. 2003. Effect of the herbicide diclofop-methyl on proton extrusion from Lolium multiflorum seedlings differing in resistance and fungal endophyte (Neotyphodium sp.) infection. Physiol. Plant. 119:429-439.

Vila-Aiub, M. M., P. Neve, K. J. Steadman, and S. B. Powles. 2005. Ecological fitness of a multiple herbicide resistant Lolium rigidum population: dynamics of seed germination and seedling emergence of targetsite vs. metabolism-based resistant and susceptible phenotypes. J. Appl. Ecol. 42:288-298.

Volenberg, D. and D. Stoltenberg. 2002a. Altered acetyl-coenzyme A carboxylase confers resistance to clethodim, fluazifop and sethoxydim in Setaria faberi and Digitaria sanguinalis. Weed Res. 42:342-350.

Volenberg, D. S. and D. E. Stoltenberg. 2002b. Giant foxtail (Setaria faberi) outcrossing and inheritance of resistance to acetyl-coenzyme A carboxylase inhibitors. Weed Sci. 50:622-627.

Walker, K. A., S. M. Ridley, T. Lewis, and J. L. Harwood. 1988. Fluazifop, a grass-selective herbicide which inhibits acetyl-CoA carboxylase in sensitive plant species. Biochem. J. 254:307-310.

Wang, T., and H. Darmency. 1997. Inheritance of sethoxydim resistance in foxtail millet, Setaria italica (L.) Beauv. Euphytica 94:69-73.

Wang, T. and H. Darmency. 1998. Cross-resistance to aryloxyphenoxypropionate and cyclohexanedione herbicides in foxtail millet (Setaria italica). Pestic. Biochem. Physiol. 59:81-88.

Webb, S. R., G. L. Durst, D. Pernich, and J. C. Hall. 2000. Interaction of cyclohexanediones with acetyl coenzyme-A carboxylase and an ar- tificial target-site antibody mimic: a comparative molecular field analysis. J. Agric. Food Chem. 48:2506-2511.

Webb, S. R. and C. J. Hall. 2002. Development and evaluation of an immunological approach for the identification of novel acetyl coenzyme A carboxylase inhibitors: assay optimization and pilote screen results. J. Agric. Food Chem. 48:1219-1228.

Werck-Reichhart, D. and R. Feyereisen. 2000. Cytochromes P450: a success story. Genome Biol. 1:3003.1-3003.9.

Werck-Reichhart, D., A. Hehn, and L. Didierjean. 2000. Cytochromes P450 for engineering herbicide tolerance. Trends Plant Sci. 5:116123.

Wiederholt, R. J. and D. E. Stoltenberg. 1996a. Similar fitness among large crabgrass (Digitaria sanguinalis) accessions resistant or susceptible to acetyl-coenzyme A carboxylase inhibitors. Weed Technol. 10:42-49.

Wiederholt, R. J. and D. E. Stoltenberg. 1996b. Absence of differential fitness among giant foxtail (Setaria faberi) accessions resistant and susceptible to acetyl-coenzyme A carboxylase inhibitors. Weed Sci. 44: $18-24$.

Yu, Q., L.J.S. Friesen, X.-Q. Zhang, and S. B. Powles. 2004. Tolerance to acetolactate synthase and acetyl-coenzyme A carboxylase inhibiting herbicides in Vulpia bromoides is conferred by two co-existing resistance mechanisms. Pestic. Biochem. Physiol. 78:21-30.

Zagnitko, O., J. Jelenska, G. Tevzadze, R. Haselkorn, and P. Gornicki. 2001. An isoleucine/leucine residue in the carboxyltransferase domain of acetyl-CoA carboxylase is critical for interaction with aryloxyphenoxypropionate and cyclohexanedione inhibitors. Proc. Natl. Acad. Sci. USA 98:6617-6622.

Zhang, H., B. Tweel, J. Li, and L. Tong. 2004a. Crystal structure of the carboxyltransferase domain of acetyl-coenzyme A carboxylase in complex with CP-640186. Structure 12:1683-1691.

Zhang, H., B. Tweel, and L. Tong. 2004b. Molecular basis for the inhibition of the carboxyltransferase domain of acetyl-coenzyme-A carboxylase by haloxyfop and diclofop. Proc. Natl. Acad. Sci. USA 101: $5910-5915$.

Zhang, H., Z. Yang, Y. Shen, and L. Tong. 2003. Crystal structure of the carboxyltransferase domain of acetyl-coenzyme A carboxylase. Science 299:2064-2067.

Received December 16, 2004, and approved April 26, 2005. 